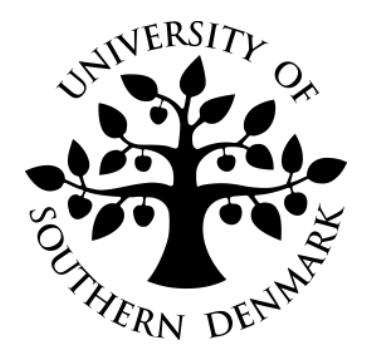

\title{
Historical origins of cultural supply in Italy
}

by

Karol Jan Borowiecki

Discussion Papers on Business and Economics

No. 3/2015

FURTHER INFORMATION Department of Business and Economics Faculty of Business and Social Sciences University of Southern Denmark Campusvej 55, DK-5230 Odense M Denmark 


\title{
Historical origins of cultural supply in Italy
}

\author{
By Karol Jan Borowiecki \\ Department of Business and Economics, University of Southern Denmark, Odense, Denmark, and Department of Economic \\ History, Lund University; e-mail: kjb@sam.sdu.dk
}

\begin{abstract}
I investigate the consequences of long-run persistency of a society's preferences for cultural goods. Historical cultural activity is approximated with the frequency of births of music composers during the Renaissance and is linked with contemporary measures of cultural activity in Italian provinces. Areas with a one percent higher number of composer births nowadays show an up to $0.29 \%$ higher supply of classical concerts and $0.16 \%$ more opera performances. Classical concerts and opera performances have also rather bigger audiences and obtain greater revenues in provinces that have been culturally active in the past. Today, those provinces also exhibit a somewhat lower supply of other forms of entertainment (e.g., sport events), thereby implying a tantalising divergence in societies' cultural preferences which is attributable to events rooted in the past. It is also shown that the geography of composer births is remarkably persistent over a period of seven centuries.
\end{abstract}

JEL classification: N33, N34, O10, Z1, Z10 


\section{Introduction}

Some cities produce an abundance of cultural activities, while other cities do not. However, little is known about the sources of contemporary cultural activity. Why do street musicians in Vienna have symphonic orchestra quality? This may come from the city's history of classical composers, generating local interest in this type of culture. Or why can artists be spotted at every corner of central Paris? Once again, historical demand for artistic goods and services might have persisted and thus influence artistic milieus in the French capital today. Obviously, cultural achievements are hardly a random incident but rather a market response to the demand. Cultural demand is nowadays primarily driven by the elite, and this was even more the case in the past. Arguably, the elite is also most likely to transmit social norms across generations, as a conduct in accordance with such norms allows the elites to differentiate themselves from the rest of the population. ${ }^{1}$ This transmission might conceivably have facilitated the persistency of cultural preferences. In this article, I investigate this perseverance and address the question of how persistent (in the very long run) the geography of cultural production is.

The choice of the cultural angle of this research is motivated by the attention that creative industries have recently been given by policy makers. The cultural and creative sectors are nowadays among the most dynamic sectors in the world economy and are arguably a substantial source of growth in the EU (European Commission, 2012). Those industries are further believed to constitute opportunities for developing countries to leapfrog into emerging high-growth areas of the world economy (UNCTAD, 2010). As such, the secondary aim of the article is to illuminate the role of history in explaining contemporary cultural activity; currently those aspects are perhaps somewhat neglected by the authorities. The focus of this study is on Italy, as it is a country which offers an ideal research setting for the purpose of this investigation. Italy has seen outstanding cultural accomplishments in the distant past, especially, but not only, during the Renaissance. Those developments occurred in some, but not all, areas across Italy thereby resulting in a high degree of geographic variation. Similarly, heterogeneity can be observed in contemporary cultural supply, as artistic activities are decentralised and usually managed at a local level.

As a starting point, I explore the role of economic and cultural shocks that have been associated with the Renaissance period in explaining the contemporary cultural behaviour of a society. The Italian Renaissance was a period of great cultural change and achievement,

\footnotetext{
${ }^{1}$ See, for example, Algan and Cahus (2010) who disclose how parental investment creates long-term persistency of attitudes.
} 
with some of the greatest developments occurring in the field of music. As a result, during the Renaissance music reached new heights of cultural respectability and contributed to a remarkable development of music production in the centuries to come across Europe. I demonstrate that areas with established music production during the Renaissance disclose markedly higher levels of cultural production today (primarily, but not only, related to activities associated with classical music). Furthermore, this study shows that provinces with a rich cultural past nowadays supply a somewhat lower amount of other entertainment activities, such as sport events. The results point to a tantalising divergence in society's cultural preferences which is attributable to events rooted far back in the past.

I study the long-term persistency of a society's preference towards cultural activities by analysing a unique data set that covers the frequency of births of prominent composers in Italy over a period of seven centuries. The data set employed covers around 1,700 composers and is based on all classical composers who are listed in Grove Music Online (2011). ${ }^{2}$ In many (but not all) areas across Italy some of the greatest composers of all times were born during the Renaissance. This emergence was certainly not a random incident and would have been stimulated by society's behaviour, manifested in released funding for music education and production. The frequency of births per locality will therefore be used as an approximation for a society's preference towards cultural activities. The historical composer database is then linked with contemporaneous entertainment activity supply in Italian provinces. Those records are available for a large array of activities, ranging from cultural events (e.g. classical concerts) to non-cultural attractions (e.g. soccer matches).

The results imply a strong and positive association between historical composer births and the contemporary supply of entertainment activities that are directly related with classical music. Provinces with a higher frequency of composer births during the Renaissance nowadays supply more opera performances or classical concerts. The positive relationship is also found for other cultural activities that are not directly related to classical music. In provinces where more or better composers were born, there is today a richer supply of theatre, opera, revue and musical performances or jazz concerts. These results are robust to a large number of tests. For example, tourism flows are found to be of little relevance, suggesting that the observed patterns are not distorted by the demands of incoming tourists but perhaps reflect the preferences of the society. It is also disclosed that provinces with a less distinguished cultural past today exhibit a somewhat greater number of other forms of

\footnotetext{
${ }^{2}$ The term classical composer is used here in order to denote the sample covered in this research which consists of composers of classical music (serious music) as opposed to composers of other types of music (e.g. jazz).
} 
entertainment, such as sports events. Furthermore, it is shown that the emergence of important composers is not a random incident but relies heavily on historical path dependence: the number of composer births per province is highly related across centuries. The results imply a remarkable persistency in the geographic concentration of artistic activity over a period of seven centuries. However, the observed patterns may have origins which stretch even further back in time.

It is difficult to attribute society's contemporary behaviour with regard to cultural production to any particular historical incident. The emergence of important composers during the Renaissance period was not an exogenous event, and as such possibly even earlier influences have shaped contemporary social norms. For example, the development of Etruscan communities or Roman settlements during ancient times might have set in motion some forces that contributed to the consecutive development during the Middle Ages. Those stimuli might have led to the remarkable cultural growth during the Renaissance (and the emergence of influential composers), thus impacting the development path of a society for several successive centuries. The contribution of this article is therefore limited to the demonstration of historical persistency of certain preferences towards culture as well as how this perseverance is shaped by prominent individuals in the long run, as opposed to the identification of any specific historical factors or time-periods that have been particularly meaningful in shaping future development.

This paper is related to recent research on the long-run persistency of social norms and cultural traits. Guiso et al. (2008) disclose that Northern Italian cities that were independent during the Middle Ages are characterised by a greater degree of interpersonal trust today. ${ }^{3}$ Higher degrees of trust as well as lower corruption levels are found in regions that have been historically affiliated with the Habsburg Empire (Becker et al., 2011). Nunn and Wantchekon (2011) argue that individuals whose ancestors were heavily raided during the slave trade nowadays exhibit less trust in their neighbours. Voigtlaender and Voth (2012) find that certain types of behaviour, such as, for example, inter-ethnic violence, might persist over long periods even if there is no direct economic benefit. Historical religious and social norms can influence long-term economic and demographic development of a society, as elaborately outlined by Botticini and Eckstein (2007). Of relevance to this research are also studies on the socio-economic impact of factors such as historical population composition (Putterman and Weil, 2010) or technological starting conditions (Comin et al., 2010).

\footnotetext{
${ }^{3}$ In a Robustness Test, it is disclosed that the results presented in the underlying study are not driven by Italy's North-South Divergence.
} 
Previous literature within this area usually illustrates the role of historical determinants in the development of certain social norms. Relative to this research, the main contribution of the present paper is to disclose how those norms may influence the behaviour of a society in the long run. The contribution is thus an analysis of the long-lasting effects of certain preference endowments.

Therefore, this paper also links to an emerging literature strand on endogenous preference (Fehr and Hoff, 2011). Traditionally, in economics, preferences have been treated as exogenously given, which is in stark contrast to other social sciences (e.g. psychology), where it is disputed that institutions and other socially defined variables can influence preferences. Conclusive scientific evidence showing that preferences are causally shaped by social institutional settings and cultural traits is, however, practically non-existent (Fehr and Hoff, 2011). The underlying research contributes to this strand as it provides some indication of the historical persistency of a society's taste.

Of particular relevance to this research is a recent game-theoretical study by Acemoglu and Jackson (2011). The authors formalise the notion of social norms as frames of reference and illuminate the development of social preferences over time. It is posited that "the impact of history is potentially countered by 'prominent' agents, whose actions are more visible. In particular, actions by prominent agents are observed by all future agents and this creates the possibility that future generations will coordinate on the action of a prominent agent" (p. 31). As such, one may argue that those prominent individuals were the patrons of music composers, since it is very likely that the status of the composer was - though changing over time - still much linked with the patronage of the church or some noble master. By investigating the power to influence the behaviour of future generations, the present study could be then understood as a formal test of those theoretical predictions. ${ }^{4}$

The rest of the paper is organised as follows: the second section includes a description of the data used and presents the historical as well as contemporary cultural aspects relevant to this research. The third section introduces the empirical methodology and discusses the results. The fourth section presents concluding remarks.

\section{Data and Context}

This study employs data on the extent of cultural activity at two points in time - the Renaissance period and the present day. The indicator for Renaissance cultural activity in an

\footnotetext{
${ }^{4}$ See also Fernandez (2011) for a substantial review of related economic research on culture (as a system of beliefs and social norms, not as cultural practices which are the focus in the present study).
} 
area is the number of births of prominent composers. In general, one would prefer to measure the cultural importance of a region by studying the number of composers who worked there. This is unfortunately out of the scope of this paper since information on place of work for a sample of this size is not consistently available. Biographical material for some of the covered artists, especially with regard to migration histories, is very limited. Similar data constraints apply to a measure of the number of works created or performed in a location, which arguably could reflect consumers' cultural preferences with greater precision. With the intention to use clear, objective and consistently available information, the number of composer births is used as the primary measure of cultural activity. ${ }^{5}$ Note that in an attempt to control for the quality of the composers covered, a secondary measure based on the space allocated in a biographic entry is further introduced.

The vast emergence of outstanding composers during the Renaissance in Italy did not occur by chance and was potentially stimulated by several related factors, which are discussed below. Italy offers a particularly useful setting for the purpose of this analysis due to its political fragmentation: especially historical but also contemporary cultural activities are hardly affected by central authorities. As a result, there is rich variation in cultural supply at the provincial level. ${ }^{6}$ Therefore, it is possible to compare cultural activity of the Renaissance period with cultural supply in the same location around four centuries later.

\subsection{Renaissance and Cultural Achievements}

The Italian Renaissance was not only the (presumably) most important era in Italy's cultural history but also a meaningful precursor and source of inspiration for European Renaissance. Societal development and cultural change began in Italy around the end of the $13^{\text {th }}$ century and lasted until the $16^{\text {th }}$ century, thus branding the transition between Medieval and Early Modern Europe. ${ }^{7}$ The era is acknowledged for its cultural achievements in the fields of literature, philosophy, science, visual arts, architecture, theatre, but also, and possibly of greatest importance, in music. In fact, Italian music composition exercised a dominant influence on subsequent European music production for a period of several consecutive centuries.

\footnotetext{
${ }^{5}$ See also Appendix 5 for an assessment of the potentially arising bias due to the issue of migration.

${ }^{6}$ Throughout the article, I refer to Italy as the area under contemporary borders.

${ }^{7}$ The exact duration of the Renaissance period differ across countries and also across cultural disciplines. Music historians usually agree to start the era around 1400 and to close it around 1600. These are also the cut-off dates used for the identification of Renaissance composers in the applied analysis.
} 
Music reached new heights of cultural respectability and became, for the first time, self-sufficient. The demand for music was stimulated by the elites of Italian city-states, which exhibited exceptional economic growth during the Renaissance. Funding has therefore been available and was released by the Italian courts into the cultural sphere with the desire to generate a positive assertion of their own identities. The extent of geographic fragmentation in Italy and the resulting competition between the aristocratic courts are argued to be an important driver for the emergence of exceptional composers during the period analysed (Vaubel, 2005). Music quickly developed into a vehicle for personal expression and was increasingly often composed to express the political atmosphere of the period (Atlas, 1998). Another source of demand came from the church, which often commissioned works and further stimulated music composition. In fact, sacred and secular music benefited from each other and contributed to the remarkable heritage both in terms of quantity and quality. Furthermore, with the emergence of a bourgeois class, the demand for music as entertainment created additional incentives for music production. This is particularly attributable to the development of printing, which facilitated the distribution of music on a wide scale.

These stimuli on the demand side triggered a series of important innovations. Music education was institutionalised and based in the newly founded music conservatoires (e.g. Santa Maria di Loreto in Naples in 1537). Those institutions created platforms for dedicated music training for the young and facilitated access to music education. The presence of music conservatoires also enabled the improvement of educational practices and further contributed to the commercialisation of music in the early $17^{\text {th }}$ century. Next, a long series of important innovations of musical instruments and their production processes occurred. Stradivari, Guarneri and many other musical instrument makers of lasting fame developed and crafted violins, violas and cellos that have maintained most of their characteristics into modern days. Moreover, substantial innovations in the production of keyboard instruments ultimately led to the invention of the modern piano during the $17^{\text {th }}$ century. Relevant technological developments also occurred in architecture, which enabled the construction of buildings with more extreme interiors and superior resonance, stimulating the creative output of numerous artists. For example, the Basilica of Saint Mark, completed in 1617, with its multiple choir lofts inspired the Venetian polychoral style and influenced the works of several consecutive composers, such as Andrea Gabrieli, Claudio Monteverdi or Giovanni Gabrieli (Crocker, 1966).

All in all, wealth shocks and a shift of the elites' preferences towards cultural goods triggered forces that determined the music production and emergence of talent. 
Improvements in the available technology, education and infrastructure created not only incentives but also opportunities for composers. As a result, the profession was well sought after, the career as a composer became highly regarded and consequently a large wave of composers emerged.

At this stage it should be mentioned that the music-related developments also benefited other cultural areas. For example, the newly constructed spacious and resonant buildings would often hold theatre performances and thus facilitated the development of the Italian theatre. ${ }^{8}$ In addition, as music was frequently used in theatrical performances, the association with music development was simultaneously reinforced.

\subsection{Contemporary Cultural Supply}

Nowadays in Italy there is no official definition of culture, nor are the boundaries of the cultural area clearly defined by government. The Ministry of Heritage and Cultural Activities is formally entrusted with supervision of a wide range of cultural institutions, such as museums, libraries and archives; visual arts, performing arts and cinema; and copyright (Bodo and Bodo, 2011). The effective authority is, however, delegated to the Regional Boards for Cultural Goods and Landscapes, and the local Soprintendenze. ${ }^{9}$ This is in line with a decentralisation process which began in the 1970s. Usually, the municipalities are the most active public actors on the cultural scene in Italy. Through their municipal departments for culture (Assessorati Comunali alla Cultura) they play an important role in the direct and indirect management of cultural institutions. Furthermore, local authorities seem to be aware of the potential benefits of a strong culture and arts sector and are actively involved in policies fostering those activities in their localities (Bodo and Bodo, 2011).

\subsection{Data Sources}

This research is based on data that come primarily from two sources: SIAE Yearbook of the Entertainment Activity 2007 (Società Italiana degli Autori ed Editori - the Italian Authors and Publishers Association) and Grove Music Online (2011). SIAE (2007) shows the number of performances, attendance (i.e., admissions with ticket, including admissions with season ticket), and three measures of financial performance: box office revenue per province, audience expenditure and turnover. The latest available records are for the year 2007, in

\footnotetext{
${ }_{9}^{8}$ In fact, even nowadays Italian opera houses often hold theatre performances.

${ }^{9}$ Five out of 20 regions are autonomous with more extended competencies also in the cultural field. Three of these regions (Valle d'Aosta, Sicily and Trentino Alto Adige) exercise exclusive and direct legislative and administrative responsibility for their own heritage assets, museums and sites (Bodo and Bodo, 2011).
} 
which Italy comprised 107 provinces. ${ }^{10}$ The number of tickets sold represents the number of attendees at the performance where entry tickets (purchased at the box office or by subscription) are required. The box office revenue is the amount spent on tickets and subscriptions. Audience expenditure is the box office revenue plus any other expenses paid by the audience, such as fees for advance sales, reservation of tables, cloakroom services, consumption at the bar, etc. The turnover consists of audience expenditure plus other proceeds of the organiser from the implementation of the show, such as advertising activities, sponsorships, public and private grants, etc. All this information is displayed for live performing arts (cultural events), which include concerts and theatre activities. The concert aggregate includes classical concerts (band and choral concerts, even if the repertoire may not be purely classical), jazz concerts and pop music concerts. The theatre aggregate consists of theatre, opera, revue and musical; ballet; puppets and marionettes; performing arts and circuses.

The database also provides records for other forms of entertainment, such as sports events, dance activities and concertinos; touring amusement, exhibitions and shows; multigenre activities; and cinema. Dance activities refer to dancing to an orchestra and dancing to recorded music. Concertinos consist of musical performances (live or recorded) that are only an additional element to some other activities or entertainments, for example live piano music in restaurants or bars. As it is not possible to disclose whether it was the cultural or artistic attraction of the performance or other factors such as, for example, the quality of the food served at the restaurant that attracted the customer, this category is not included in any of the cultural activity aggregates. Sports events consist of the following sub-categories: soccer (international and national leagues), team sports other than soccer (such as basketball, volleyball, rugby and baseball), individual sports (boxing, cycle racing, athletics, tennis, show-jumping, motor racing, speed boat racing and horse racing), other sports (such as swimming and water polo or winter sports), bowling and go-karts. Touring amusements include both single exhibitions and exhibitions inside amusement and leisure parks, as well as admissions to parks. The exhibitions and shows category is composed of profit-making exhibition activities. This category includes the exhibition of goods to be sold (antiques, carpets, etc.) and trade fairs. Multi-genre includes activities that may not be referable to a unique kind of event, like open-air shows or religious festivals. Cinema is not included as one

\footnotetext{
${ }^{10}$ The records are also available for the year 2006 and are used in a robustness specification. Data on more recent years are available from SIAE for $€ 56,700$ per year, which substantially hinders the records being used for academic purposes. Previous years have a fundamentally different structure and are of limited use in this research.
} 
of the cultural activities, since it is not live performing arts and has a fundamentally different role to concerts or theatres, which is the distribution rather than the production of a cultural good.

The second database used covers all composers born in Italy and has been obtained from Grove Music Online (2011). The chosen encyclopedia is the leading resource for music research and contains more than 50,000 signed articles and 30,000 biographies. ${ }^{11}$ Given the large size of the source dictionary, the data has been obtained by means of an innovative purpose-built computer application. The aim of the application is to automate information extraction from Grove Music Online through a search for composers born in Italy. The automated extraction method eliminates human error, and hence the reliability of the database has supposedly been optimised. The acquired sample is then processed to extract records, such as full name, birth place, death place, birth date and death date. Second, a word count is calculated for each section - that is, life, works, bibliography and writings - in the results pages. The length of a biographical entry is arguably a reliable approximation for the quality of an individual. Appendix 1 describes in more detail how the software works.

The obtained data set consists of 2,265 composers whose nationality is provided as 'Italian'. ${ }^{12}$ The following adjustments have been made. The precise birthplaces of eighteen composers are equivocal as only the most likely birth location has been recorded (e.g. '?Pontecorvo'). For those composers the record provided has been used in order to identify the birth province. Even if the birthplace was not the listed location, most likely the birth occurred somewhere in the proximity. In nineteen cases, the birthplace is even more tentative (e.g. only the region or part of Italy is known). Those composers have been excluded from the analysis. Two further composers were born in places that are not located within current borders of Italy (i.e. Lugano in Switzerland and Pirano in Slovenia). Those observations as well as records not stating composers' dates of birth have been dropped.

Finally, this study uses records on the contemporary population size, economic performance and educational attainment of Italian provinces. The population size at provincial level in 2007 has been obtained from the annual survey on the labour force

\footnotetext{
${ }^{11}$ The source dictionary has previously been used to acquire data about composers. Most notably, Scherer (2004) obtained records for a sample of 646 composers born between 1650 and 1849 in order to study, among other things, the profession's transition from court and church employment to freelance activity.

${ }^{12}$ The birth locations of those artists have been carefully linked with the areas that fall within the boundaries of contemporary provinces. The boundaries of some of the areas have not always remained constant over time and such information, especially concerning small villages, is sometimes not well recorded. Therefore, in a robustness test I restrict the sample to composers born in towns which are today capitals of one of the studied provinces. This exercise delivers very consistent results throughout all specifications (not reported), which supports the view that the results are not driven by changes in the boundaries.
} 
(ISTAT, 2008). Economic welfare and efficiency are measured by inclusion of the value added series, which is expressed in current values for the year 2007 at the province level (ISTAT, 2011). Education data on province level is provided in the population census, which is conducted every 10 years and is last available for the year 2001. As in 2001 Italy consisted only of 102 provinces, the regressions are based on 102 observations.

\subsection{Data overview}

Summary statistics on the number of performances, total audiences and box office for live performing arts (cultural activities) and other forms of entertainment are presented in Panel A and Panel B of Table 1, respectively. The concert aggregate accounts for 357 performances per province and consists of classical, jazz and pop concerts. The predominant cultural activity aggregate is the theatre category that accounts for more than 1,500 performances in the average province and consists primarily of theatre and performing arts productions. Other forms of entertainment consist of sports events, dance and concertinos, touring amusement, exhibitions and shows, multi-genre activities, and cinema. Panel $\mathrm{C}$ of Table 1 reports an income measure, population size and share of educated population of the average province. Table A2 in Appendix 2 provides summary statistics extended by audience expenditure and turnover for all the baseline categories as well as for cinema.

\section{[insert Table 1 here]}

Table 2 provides a summary of the composer data set. The earliest recorded composer births in Italy occurred in the $14^{\text {th }}$ century and the number increased sharply during the Renaissance until the $16^{\text {th }}$ century when it peaked at 421 composer births. This is consistent with Borowiecki and O'Hagan (2012) who argue that by the late $16^{\text {th }}$ century Italy was the musical centre of Europe and accounted globally for around $40 \%$ of important composers. Similar patterns arise for the length of biographical entries. In the $16^{\text {th }}$ century the average length of a biography was at its peak of around two thousand words, implying the high quality of those composers. The disclosed length of biographies is even more impressive if one considers that records are generally scarcer for historically distant periods. In later centuries, both the number of births as well as the length of biographical entries were in a steady decline, which resonates the decreasing role of music in Italy. While the observed increase in the number of composer births or length of biographical entry could be partly associated with potentially more accurate record-keeping in the $16^{\text {th }}$ century than in the $14^{\text {th }}$ century, the later decline in those variables supports the posited importance of this period. 
The map in Figure 1 shows the frequency of composer births during the Renaissance in Italy within its 2007 borders. Areas are marked in varying shades of blue (grey), depending on the frequency of composer births. Provinces marked with a darker shade of blue saw a higher number of composer births. The northern part of Italy, which is usually believed to be the better developed part, is generally characterised by a higher number of composer births.

\section{[insert Figure 1 here]}

It can also be observed that the frequency of birth varied substantially, even at the province level. Provinces in immediate proximity to each other experienced a very different history of artistic emergence. While, for example, not even one composer was born during the Renaissance in either of the neighbouring provinces of Prato and Pistoia, the surrounding provinces were important centres of music: Florence (birthplace of 33 composers), Bologna (33), Modena (12) and Lucca (8). ${ }^{13}$ The same contrast can be observed in the southern part of Italy. In Naples, for example, 26 composers emerged during the $15^{\text {th }}$ and $16^{\text {th }}$ centuries, whereas in all four surrounding provinces (i.e. Caserta, Beneventa, Avellino and Salerno) in total only 4 composers were born. ${ }^{14}$ This is the level of variation at the province level which will be exploited in the quantitative analysis of this study.

\section{[insert Figure 2 here]}

Figure 2 shows the geographical distribution of cultural activities. Northern and central regions are areas with a relatively high supply of cultural activities per population. As in Figure 1, it can be observed that there is sufficient variation at the province level, with areas of very high cultural activity supply immediately adjacent to those with low supply.

\section{Empirical Results}

It is suggested that the geography of contemporary cultural supply coincides with cultural achievements during Renaissance. As described in the previous section, the developments associated with the Renaissance period constituted a common shock that increased cultural activity. In some provinces the emergence of important composers has been triggered, while in others not. It is demonstrated that across a range of cultural activities, provinces with

\footnotetext{
${ }^{13}$ It is further interesting to observe that historically the cities of Prato and Pistoia were not fundamentally different places than the capitals of the four neighbouring provinces. For example, the city of Pistoia obtained its independence in 1117, less than a year later than the average of the four neighbouring capital cities. Pistoia served as the domicile for an independent local authority as well as a bishop, similar to the neighbouring provincial capitals, and had a population size in 1871 comparable to that of Modena (Guiso, Sapienza and Zingales, 2008).

${ }^{14}$ These observations would be equally extreme if the total length of biographical entries was considered. The Italian North-South divergence determines some of the geographic heterogeneity, however as disclosed in a robustness test, does not explain the persistency.
} 
meaningful cultural records in the Renaissance are characterised by higher contemporary supply. It is also disclosed that this emergence of cultural talent is geographically remarkably persistent over several consecutive centuries.

\subsection{Methodology}

The aim of this research is to investigate the long-term persistency of certain preferences of a society towards cultural activities. In order to conduct such analysis the existence of a relationship between contemporary cultural supply and historical cultural achievements are estimated. As the latest available records on contemporary cultural supply are available for the year 2007, the focus of this analysis is directed on this year. ${ }^{15}$ It is of much greater difficulty to measure the value of cultural wealth of a geographic region and out of scope to do so directly for historical time periods. For this reason in the underlying study cultural activity needs to be approximated and it is done so by measuring the number of historical births of prominent composers or by estimating their successive importance. The significance of an artist is conventionally measured with the length of biographical entry. It is likely that on average the biographical entry of the better composer would be longer. The chosen period of births are the $15^{\text {th }}$ and $16^{\text {th }}$ centuries, from now on termed the Renaissance. This is the earliest time period in which a meaningful number of composers have been born. ${ }^{16}$ As several other factors could potentially influence contemporary cultural supply, it is necessary to control for them and utilise a formal econometric setting. For this reason, the following model is employed:

$\log \left(\right.$ Contemporary Cultural Activity $\left.\mathrm{pc}_{\mathrm{i}}\right)=\alpha_{0}+\alpha_{1} \log ($ Historical Cultural Activity $\mathrm{i})+\alpha_{2}$ $\log \left(\right.$ Value Added $\left._{\mathrm{pc}, \mathrm{i}}\right)+\alpha_{3} \log \left(\right.$ Population $\left._{\mathrm{i}}\right)+$ Education $_{\mathrm{i}}+\boldsymbol{\alpha}$ Region $_{\mathrm{i}}+\varepsilon_{\mathrm{i}}$

Equation 1 estimates the determinants of contemporary cultural activity in province $i$ (Contemporary Cultural Activity $p c, i$ ). The available datasets allow this variable to be measured in three ways. It will be estimated for each category or type of activity with the logged number of performances per capita, logged total audience size and box office revenue. Of primary interest is the coefficient $\alpha_{1}$, which exhibits the relationship between contemporary and historical cultural activity. Cultural activity of the past is obtained in two

\footnotetext{
${ }^{15}$ The entertainment activity data set is available also for the year 2006, which is employed in a robustness test in Appendix 2.

${ }^{16}$ In a later section I analyse also the association between composer births during Renaissance and consecutive periods.
} 
ways: as the number of composer births that occurred during the Renaissance (that is in the $15^{\text {th }}$ and $16^{\text {th }}$ centuries) or, in an attempt to account for composers' quality, it is calculated for each province as the total word length of biographical entries of composers born during the Renaissance.

In order to account for wealth heterogeneity between provinces, I include controls for value added per capita for $2007 .{ }^{17}$ I further introduce population size in a province in 2007 to control for economies of scale and agglomeration. The model includes also control variables for the shares of population that have at least a secondary school degree. The rational for this is that cultural shows are predominantly demanded by better educated people (e.g. AtecaAmestoy, 2008). These three fundamental control variables are included in every regression, because they are obvious contemporary determinants of cultural activity. In order to deal with further unobserved geographical heterogeneity, I include a set of indicator functions that take the value of one for each of the twenty Italian regions. The model contains also a constant $\left(\alpha_{0}\right)$ and standard errors clustered at the region level $\left(\varepsilon_{i}\right)$, allowing for correlations between observations within a single region, but remaining independent between regions.

\subsection{Contemporary Cultural Activities}

I begin by investigating the relationship between historical preference towards cultural production, approximated with births of composers during Renaissance and contemporary cultural activities supply. Panel A of Table 3 shows the association between composer births and the logged number of performances per capita (columns 1 and 2), logged audience size (columns 3 and 4) or logged box office income (columns 5 and 6) in each type of activity in a province. The estimation is based on the previously discussed Model 1 and contains the set of introduced control variables. The coefficient for concert supply (number of performances) is positive and significant in both panels. The results imply that a one percent higher number of composer births during Renaissance coincides with contemporary around $0.16 \%$ more concerts per one million citizens.

\section{[insert Table 3 here]}

It is likely that there exists heterogeneity in the observed returns depending on the quality of the composer. The association between cultural supply and some of the greatest

\footnotetext{
${ }^{17}$ Note that inclusion of price controls into Equation 1 would lead to biased and inconsistent OLS estimates due to the simultaneity problem that the paper implicitly recognizes. The incorporated controls for the wealth of a population and population size are believed to be particularly strong controls for incentives to organize a performance. Appendix 7 shows further that there does not exist any revenue premium obtained in provinces with a greater cultural activity in the past.
} 
composers might be different than with the average prominent artist. I allow therefore for the possibility of geographic concentration of outstanding talent and take account of composers' quality by considering the length of their biographical entries. This measure aggregates the word length of biographical entries of all composers born during Renaissance per province and is expressed in thousands of words. The results are reported in Panel B of Table 3. The point estimates imply a positive and statistically significant association with the number of concert-type of performances. The coefficient implies that a one-percent increase in the length of biographical entries of all composers in a province would yield a very consistent 0.15 rise in the number of concerts. While the association with audience size and box office income are estimated to be positive, the coefficients lie outside the usual confidence intervals.

So far the analysis has looked at two types of aggregated cultural activities. Next, I disaggregate those categories and re-estimate the associations between historical cultural activity and number of performances supplied for a wide range of sub-categories. In analogy with the previous approach, historical cultural activity is first measured with the number of composer births in the Renaissance and the results are reported in Panel A of Table 4. The association between composer births and cultural supply is positive and statistically meaningful for supply of classical concerts per capita, as well as opera performances. The coefficients imply that the strongest association is found for classical concerts. A one-percent increase in the number of composer births yields a $0.29 \%$ higher number of classical concerts.

\section{[insert Table 4 here]}

Panel B of Table 4 reports results for estimations where the length of biographical entries is used as an approximation for historical cultural wealth. The point estimates are now estimated with greater precision, implying that there is some non-linear effect depending on the quality of the historical composer. The association between the total length of biographical entries of composers born in a province are the strongest with the number of classical and jazz concerts per capita within the concert activity aggregate as well as for the number of theatre, opera and revue and musical performances per capita within the theatre activity aggregate. Throughout all studied events the association is in general positive, even if not always statistically significant. The only negative coefficient is found for circus, and puppets and marionettes performances, which are supposedly performances with a lower cultural and artistic value.

A striking feature can be deducted from the findings presented so far: 
Result 1. There exists a strong association between historical composer births and contemporary activities that are closely related with classical music. In provinces where more or where better composers have been born, there are nowadays performed more classical concerts and operas.

\section{[insert Table 5 here]}

It is of great interest to understand also how do the audience size or revenues differ for each of the categories. Table 5 shows the corresponding point estimates for the classical concert and opera categories. It can be viewed that in provinces with a richer cultural past, not only more performances of both types take place, but also higher audiences are observed (even if the coefficients are not significant for both measures of historical cultural activity) and higher box office revenues are achieved (especially with classical concerts). These coefficients indicate that composer births predict not only the variety of cultural activity nowadays, but also its amount and financial revenue. ${ }^{18}$ The associations for all remaining live performing arts can be viewed in Tables A4.1 and A4.2 (Appendix 4). The results deliver usually insignificant associations with audience size and box office revenues for the remaining activities.

Next, other forms of entertainment are explored.

\subsection{Other forms of entertainment}

The disclosed results so far could be explained in two ways. One explanation would be consistent with the previously suggested mechanism of a path dependence of cultural demand. Cultural preferences could be persistent over long periods of time and thus provinces with a more meaningful cultural past are also providing better artistic supply in successive time periods. An alternative explanation is that provinces with more important accomplishments in the past are simply more active throughout a wide range of various activities and provide a greater supply of any type of leisure event nowadays. This alternative hypothesis is tested by the inclusion of a large set of other forms of entertainment which are then linked with historical composer births or their quality.

The analysis of the association between historical cultural activity and the number of other forms of entertainment supplied nowadays is presented in Table 6. The point estimates for the number of composer births and length of biographical entries are presented in Panels

\footnotetext{
${ }^{18}$ Identical conclusions regarding revenues can be derived if the other two measures - audience expenditure or turnover - are used (see Appendix 3).
} 
$\mathrm{A}$ and $\mathrm{B}$, respectively. It can be observed that a majority of the estimated coefficients are negative and some are even statistically significant. The results indicate that in provinces where more or better composers have been born in the past, the supply of sport performances per capita is significantly lower. Historical composer births higher by one percent correspond with around $0.11 \%$ lower number of sports events in a province. The relationship is also negative, albeit not always significant, for dance performances, concertinos, as well as multigenre activities. ${ }^{19}$ Exhibitions and shows activities are the only category of events that correspond positively with composer births however the association is outside the usual statistical confidence levels.

\section{[insert Table 6 here]}

It has been previously shown that provinces with a meaningful cultural past are also contemporary involved in more cultural activities. The results presented in this section indicate that provinces that had greater cultural achievements in history seem to supply nowadays a lower number of non-cultural activities. The findings imply that:

Result 2. There exists a divergence in the preference of a society towards cultural and noncultural activities that is remarkably persistent over the period of more than four centuries.

Table A4.3 and A4.4 (Appendix 4) show for each of the other entertainment activities how historical cultural activity relates to contemporary total audience size or total revenue. None of the coefficients of interest are significant, implying that the main difference between provinces that had a rich cultural past and not, relates to the number of events supplied.

Appendix 5 describes some of the robustness tests that have been conducted in order to test the reliability of the disclosed results. The robustness checks include specifications based on data for the preceding year 2006 or accounting for tourism flows which typically coincide with cultural participation. The robustness section discusses further the issue of migration of composers. The matter of tourism flows is also addressed, since tourism visits coincide strongly with cultural participation in Italy (Borowiecki and Castiglione, 2014). Next, historical population measures are used in order to approximate agglomeration economies in cultural production in the past, as cultural production benefits not only due to geographic concentration of artistic talent (Borowiecki, 2013), but also urban density may be

\footnotetext{
${ }^{19}$ All dependent variables are population adjusted and measured per one million of citizens. As has been noted before, dance events and concertinos are categorized as non-cultural events as they constitute only an additional element to some other activities or entertainments, for example, live piano music in restaurants or bars. Therefore, cultural value of such events is supposedly marginal and not possible to estimate.
} 
a significant determinant of agglomerations by facilitating consumption. Finally, approximations for historical human capital are used in order to shed some light on the role of education in the past. The results emerging from all conducted tests are consistent with the baseline specifications. Appendix 6 provides information on the explanatory power of the disclosed association.

\subsection{Earlier Influence}

An interesting question concerns the timing of the effect. It is not clear whether it was the emergence of important composers that led to the remarkable divergence in cultural and noncultural activity within a province, or rather some earlier unobserved factors. Providing an answer to this question could eventually illuminate further the mechanism of the disclosed association between historical cultural wealth and contemporary cultural supply. Such analysis is however very limited, as there are hardly any quantitative records on other cultural assets of a province in earlier time periods. As a tentative approach I study the number of archaeological sites and UNESCO world heritage sites and use those variables as an approximation for prehistoric or medieval achievements. Including controls for earlier influences allows an investigation of the relative performance of the used composer births or quality variables in explaining contemporary cultural aspects. The additional data sets have been obtained from the Ministry of Cultural Heritage and Activities in Italy and UNESCO. The archaeological sites include ancient Roman, Greek and Etruscan ruins. The average province has 3.8 archaeological sites (standard deviation 7.42). The UNESCO World Heritage List includes properties that form part of the cultural and natural heritage of outstanding universal value. The year of origin of those sites is more diverse and is mostly ancient, however some originate also from the Middle Ages or even later periods. On average, there are located 0.9 UNESCO world heritage sites in a province (standard deviation $1.4)$.

The estimations are presented in Table 7. It can be observed in columns 1 and 2 that the coefficients on the archaeological sites are positive and mostly significant. The result implies that the impact of historical factors on contemporary cultural supply might be attributable to incidences from even farther past. It is nonetheless important to note that the coefficients on composer births or quality during the Renaissance remains consistent in size and is significant for classical concerts; for opera the results are less strong, but nonetheless consistent. This suggests that also factors associated with the emergence of influential composers during the 15 and 16 centuries are important in explaining contemporary supply of 
concerts. The association between the number of UNESCO world heritage sites and contemporary cultural engagements is less clear and statistically insignificant (columns 3 and 4). The coefficients on the composer birth or quality variables remain however once again stable in size and significant, especially for classical concert concerts.

[insert Table 7 here]

Interpretation of the findings is difficult. The results might point at a prevalence of very early historical factors, perhaps even related to incidences that occurred during ancient times. However, also later events, associated with the Renaissance (and approximated with composer births or quality), are found to expose meaningful relationships with activities related to music composition. In conclusion:

Result 3. Historical composer births during the Renaissance expose a strong association with contemporary related cultural activity also after one accounts for earlier historical incidences. The role of history in explaining the observed divergence is likely however to originate in even earlier, perhaps ancient periods.

\subsection{Persistency}

The focus of the conducted analysis so far has been directed at the comparison of two periods in time: a historical one (I have looked at the frequency of composer births primarily during the Renaissance) and a contemporary. The emerging results from the conducted analyses imply that some factors are remarkably persistent over the long time period of around four centuries. Little attention has been devoted however to the incidences that occurred during the centuries in-between those two points in time. In this part, I use the entire classical composer data set which contains records on the number of composer births in a province for each century and provide an investigation of the geographic persistency of artistic concentration.

\section{[insert Table 8 here]}

Table 8 presents a matrix of correlation coefficients for the number of composer births in a province in a given century. The estimated coefficients are always positive and usually highly significant. This implies a remarkable persistency in the geography: up to $86 \%$ of births in a given century are occurring in the same province as in the previous century. The correlation coefficients are usually the largest for consecutive centuries and decrease in size over time. The only insignificant correlation estimates, albeit consistently positive, are found 
between the $14^{\text {th }}$ century and periods after the $17^{\text {th }}$ century, which is presumably caused by a very low number of observations for the earliest observed century.

[insert Table 9 here]

Next, I establish a more formal framework and model the number of composer births that occurred during a century as a function of births of the previous century. The estimations are based on observations for 107 provinces and seven centuries. Table 9 presents the results. The association between composer births between two consecutive centuries is found to be positive and highly significant. This relationship is robust to the inclusion of century controls, estimated with an indicator function that takes the value one for each century and zero otherwise, as well as province fixed effects. The preferred specification that includes century and province controls (reported in column 4) implies that for ten additional composers born in a province, another three births followed in the next century in the same province. This relationship is established within the $99 \%$ confidence interval. The results point at a remarkable persistency of geographic concentration of artistic activity and the role of historical factors in explaining cultural aspects over a very long period. The findings are summarized as follows:

Result 6. The emergence of great talent is not a random incident and is highly dependent on historical path dependence. Clustering of composers is very persistent in its geography in the long-run.

\section{Conclusion}

Much attention, both at the academic and policy levels, has recently been devoted to the cultural industries. Until now, however, little has been known about the role and persistency of historical influences on contemporary cultural activity. As such, this study provides a useful contribution by investigating the origins of cultural activity in Italy. The primary focus of this research is on the period of the Renaissance, which is then linked to contemporary entertainment activity. The Italian Renaissance was characterised by remarkable developments in the cultural sector, resulting in particularly important changes in the field of music in some Italian provinces. The geographic heterogeneity in historical cultural development is exploited in this paper and it is approximated with the frequency of composer births that occurred during the $14^{\text {th }}$ to $16^{\text {th }}$ centuries. Those historical composer births are then linked to the supply of a wide range of present-day entertainment events. 
The emerging results provide some evidence on a remarkable persistency of historical factors in determining the supply of cultural activities. Italian provinces that have been culturally more developed in the past nowadays have a larger supply of cultural events, especially of those closely related to classical music. The estimated effects are large and imply about $0.29 \%$ higher supply of classical concerts in provinces that saw a one percent higher number of composer births during the Renaissance. Significant positive associations with the number of performances are also detected for other cultural activities, such as opera, theatre, revue and musical performances, and jazz concerts. Today, classical concerts and opera performances have also rather bigger audiences and obtain greater revenues in provinces that have been culturally active in the past. It is even more interesting to observe that those provinces nowadays provide a somewhat lower supply of other entertainment activities, such as sport events. The findings point to a divergence in the patterns of cultural supply which is attributable to forces that persisted over a period of several centuries. It is difficult to estimate the exact timing of the observed effects, which have likely originated in time periods even earlier than during the Renaissance. I also demonstrate an outstanding persistency in the birth location of prominent composers. Historical path dependence determines the geography of the emergence of artistic talent over a period of seven centuries.

The results presented in this study constitute an important motivation for the vast research on the history of art markets (e.g., Etro and Paganini, 2012). Historical factors are relevant determinants of today's cultural sector, and a better understanding of their role might potentially improve current decision making. From a policy perspective, the emerging findings point to the additional burden faced by some developing countries that did not experience a rich cultural past and yet direct their support towards the development of cultural industries in order to leapfrog into emerging high-growth areas of the world economy. ${ }^{20}$ Entry barriers are possibly existent primarily for the traditional artistic disciplines (such as classical music composition), hence for emerging countries it could eventually be advantageous to focus on the fostering of new artistic genres. Countries that possess meaningful cultural endowments could further exploit them in order to stimulate a positive assertion of their own identities. These considerations are provided with the cautionary remark that further analysis and case studies are required in order to illuminate effective ways to exploit historical cultural wealth.

\footnotetext{
${ }^{20}$ This article studies the historical role of Western culture, e.g. classical music, in a European country. Culture is, however, under no means limited to Western culture and it is likely that some developing countries that had other forms of cultural wealth in the past are prone to experience comparable benefits nowadays (consider for example the traditional Chinese theatre, also called the Beijing Opera).
} 


\section{Supplementary material}

Supplementary material (the Appendix) is available online at the OUP website.

\section{Acknowledgments}

The author wishes to thank Concetta Castiglione, Chris Meissner, Cormac O'Grada, John O’Hagan, Kevin O’Rourke, Peter Sandholt Jensen, Fabian Waldinger, Jeffrey Williamson, Fabrizio Zilibotti and participants at the Conference 'Culture - Potentials for development?' in Maribor, Association for Cultural Economics International Conference, Spanish Economics Society Symposium, Royal Economic Society Conference and invited seminars at the universities of Catania, Oviedo and Warsaw. 


\section{References}

Acemoglu, D. and M.O. Jackson. 2011. 'History, Expectations, and Leadership in the Evolution of Cooperation.' MIT Department of Economics Working Paper No. 11-10.

Algan, Y. and P. Cahuc. 2010. 'Inherited Trust and Growth.' American Economic Review, 100(5), 2060-92.

Ateca-Amestoy, V. 2008. 'Determining Heterogeneous Behavior for Theatre Attendance.' Journal of Cultural Economics, 32(2), 127-151.

Atlas, A.W. 1998. Renaissance Music. New York: W. W. Norton \& Company.

Becker, S., K. Boeckh, C. Hainz and L. Woessmann. 2011. 'The Empire is Dead, Long Live the Empire! Long-Run Persistence of Trust and Corruption in the Bureaucracy.' IZA Discussion Papers 5584.

Bodo, C. and S. Bodo. 2011. Compendium. Cultural Policies and Trends in Europe. Bonn: Council of Europe/ERICarts.

Borowiecki, K.J. and J. O'Hagan. 2012. 'Statistics on Classical Composers: Historical Patterns Based on Automatically Extracted Data.' Historical Social Research (Section 'Cliometrics'), 37(2), 298-314.

Borowiecki, K.J. 2013. 'Geographic Clustering and Productivity: An Instrumental Variable Approach for Classical Composers.' Journal of Urban Economics, 73, 94-110.

Borowiecki, K.J. and C. Castiglione. 2014. 'Cultural Participation and Tourism Flows.' Tourism Economics, 20(2).

Botticini, M. and Z. Eckstein. 2007. 'From Farmers to Merchants, Conversions and Diaspora: Human Capital and Jewish History.' Journal of the European Economic Association, 5(5), 885-926.

Comin, D., W. Easterly and E. Gong. 2010. 'Was the Wealth of Nations Determined in 1000 BC?' American Economic Journal: Macroeconomics, 2(3), 65-97.

Crocker, R.L. 1966. A History of Musical Style. New York: McGraw-Hill.

European Commission. 2012. Cultural and creative industries and the Europe 2020 Strategy. http://ec.europa.eu/culture/index_en.htm (accessed 3 May 2012).

Etro, F. and L. Pagani. 2012. 'The Market for Paintings in Italy During the Seventeenth Century.' The Journal of Economic History, 72(02), 423-47.

Fehr, E. and K. Hoff. 2011. 'Tastes, Castes, and Culture. The Influence of Society on Preferences.' Economic Journal, 121(556), 369-412.

Fernandez, R. 2011. 'Does Culture Matter?' In Benhabib, J., M.O. Jackson, and A. Bisin (Eds.), Handbook of Social Economics. North-Holland: Elsevier. 
Grove Music Online, Oxford Music Online. 2011. Oxford University Press, http://www.oxfordmusiconline.com (accessed during 5-8 March 2011).

Guiso, L., P. Sapienza and L. Zingales. 2008. 'Long Term Persistence.' NBER Working Paper No. 15104.

ISTAT, National Statistical Institute. 2008. Indagine sulle forze lavoro. Media 2007, http://www3.istat.it/salastampa/comunicati/non_calendario/20080417_01/, accessed July 2011.

ISTAT, National Statistical Institute. 2011. Valore aggiunto nelle province italiane, http://www.istat.it/it/archivio/4502/, accessed March 2014.

Nunn, N. and L. Wantchekon. 2011. 'The Slave Trade and the Origins of Mistrust in Africa.' American Economic Review, 101(7), 3221-52.

Putterman, L. and D.N. Weil. 2010. 'Post-1500 Population Flows and The Long-Run Determinants of Economic Growth and Inequality.' Quarterly Journal of Economics, 125(4), 1627-82.

Scherer, F.M. 2004. Quarter Notes and Bank Notes: The Economics of Music Composition in the Eighteenth and Nineteenth Centuries. Princeton: Princeton University Press.

SIAE, Societa Italiana degli Autori ed Editori. 2007. The Yearbook of the Entertainment Activity 2007. Roma: SIAE.

UNCTAD, United Nations Conference on Trade and Development. 2010. Creative Economy Report 2010. Creative Economy: A Feasible Development Option. Geneva: United Nations.

Vaubel, R. 2005. 'The role of Competition in the Rise of Baroque and Renaissance Music.' Journal of Cultural Economics, 29, 277-297.

Voigtlaender, N. and H.J. Voth. 2012. 'Persecution Perpetuated: Medieval Origins of AntiSemitic Violence in Nazi Germany.' Quarterly Journal of Economics, 127(3), 133992. 


\section{Tables}

Table 1. Summary Statistics.

Concert aggregate
Classical concert
Jazz music concert
Pop music concert
Theatre aggregate
Theatre
Opera
Revue and musical
Ballet
Puppets and marionettes
Performing arts
Circus
Sports activities
Soccer
Team sports other than soccer
Individual sports
Other sports
Dance activities and concertinos
Dance
Concertinos

Touring amusement activities Touring amusement Amusement activities

Exhibitions and shows

Multi-genre activities

Cinema

Value Added per capita (in euro)

\begin{tabular}{|c|c|c|c|c|c|}
\hline \multicolumn{6}{|c|}{ Panel A: Live performing arts } \\
\hline \multicolumn{2}{|c|}{$\begin{array}{c}\text { Number of } \\
\text { performances }\end{array}$} & \multicolumn{2}{|c|}{ Total attendance } & \multicolumn{2}{|c|}{ Box office } \\
\hline 356.8 & $(528.7)$ & 109054 & $(264568)$ & 2045.3 & $(5461.4)$ \\
\hline 135.8 & $(202.3)$ & 31057 & $(83307)$ & 367.7 & $(1156.0)$ \\
\hline 51.9 & $(110.5)$ & 6440 & $(14821)$ & 1592.8 & $(4202.7)$ \\
\hline 169 & $(246.1)$ & 71556 & $(169062)$ & 84.8 & $(210.3)$ \\
\hline 1581.6 & $(2,559.5)$ & 1314590 & $(2395676)$ & 9959.8 & $(20600.0)$ \\
\hline 782.6 & $(1,718.1)$ & 144584 & $(302824)$ & 1916.4 & $(4460.5)$ \\
\hline 28.4 & $(52.9)$ & 20489 & $(57510)$ & 897.0 & $(3794.7)$ \\
\hline 28.4 & (99.3) & 16331 & $(57041)$ & 330.9 & $(1230.3)$ \\
\hline 63.8 & $(114.0)$ & 20083 & (40829) & 293.6 & $(866.8)$ \\
\hline 31.3 & $(56.5)$ & 2099 & $(04653)$ & 9.1 & $(20.2)$ \\
\hline 452.2 & $(698.6)$ & 12753 & (31959) & 163.1 & $(410.7)$ \\
\hline 194.9 & $(254.9)$ & 10121 & $(15492)$ & 91.6 & $(206.0)$ \\
\hline \multicolumn{6}{|c|}{ Panel B: Other forms of entertainment } \\
\hline 1869.0 & $(2,178.1)$ & 261615 & $(495833)$ & 3320.9 & $(8953.6)$ \\
\hline 1077.9 & $(1,637.7)$ & 204312 & $(407674)$ & 2549.9 & $(7185.3)$ \\
\hline 143.5 & $(165.6)$ & 28412 & $(42772)$ & 299.0 & $(533.2)$ \\
\hline 77.3 & $(145.4)$ & 15300 & $(51950)$ & 357.7 & $(1713.9)$ \\
\hline 77.3 & $(116.6)$ & 77 & $(00117)$ & 0.1 & $(0.1)$ \\
\hline 8173.4 & $(8,553.8)$ & 338294 & $(413812)$ & 3099.5 & $(3744.2)$ \\
\hline 4739.8 & $(5,039.8)$ & 335532 & $(406825)$ & 3074.3 & $(3684.5)$ \\
\hline 3433.6 & $(3,953.6)$ & 2761 & $(10550)$ & 25.2 & $(95.0)$ \\
\hline 349.3 & $(702.1)$ & 101039 & $(428373)$ & 955.1 & $(3610.1)$ \\
\hline 209.5 & $(530.2)$ & 1346 & (07049) & 9.3 & $(49.0)$ \\
\hline 139.8 & (278.4) & 99693 & (427028) & 945.8 & $(3599.0)$ \\
\hline 372.9 & $(648.1)$ & 177912 & (366942) & 1031.5 & $(2460.4)$ \\
\hline 419.1 & (478.8) & 14652 & $(33796)$ & 94.8 & $(250.8)$ \\
\hline 11832.5 & (17438.5) & 1088131 & (1933735) & 6258.1 & $(11400.0)$ \\
\hline
\end{tabular}

\begin{tabular}{cc}
\hline \multicolumn{2}{c}{ Panel C: Population size and wealth } \\
\hline $22,059.5$ & $(5,477.6)$ \\
557.19 & $(636.7)$
\end{tabular}

Share of educated population (in 2001)

0.872 $(0.028)$

Note: Standard deviation in parentheses. Revenue measures reported in thousands euro. Based on 107 observations. Source: SIAE (2007). 
Table 2. Frequency of composer births and their quality by century in Italy.

\begin{tabular}{lcccc}
\hline & $\begin{array}{c}\text { Composer } \\
\text { births }\end{array}$ & & \multicolumn{2}{c}{$\begin{array}{c}\text { Length of } \\
\text { biographical entries } \\
\text { (in thousands) }\end{array}$} \\
\cline { 2 - 2 } \cline { 5 - 5 } 14 th & 7 & & 0.09 & $(0.54)$ \\
15 th & 36 & & 0.21 & $(0.76)$ \\
17 th & 421 & & 2.03 & $(4.72)$ \\
18 th & 387 & & 1.74 & $(4.19)$ \\
19 th & 346 & & 1.79 & $(4.01)$ \\
20th & 238 & & 1.00 & $(2.03)$ \\
\hline
\end{tabular}

Source: Grove Music Online (2011).

Note: Standard deviation in parentheses. 
Table 3. Historical composer births and contemporary live performing arts.

\begin{tabular}{|c|c|c|c|c|c|c|}
\hline \multirow[t]{3}{*}{ Dependent variable } & \multicolumn{2}{|c|}{ Log(Performances) } & \multicolumn{2}{|c|}{ Log(Attendance) } & \multicolumn{2}{|c|}{$\log ($ Box office $)$} \\
\hline & $\begin{array}{l}\text { Concert } \\
\text { aggregate } \\
(1)\end{array}$ & $\begin{array}{c}\text { Theatre } \\
\text { aggregate } \\
(2)\end{array}$ & $\begin{array}{c}\text { Concert } \\
\text { aggregate } \\
\text { (3) }\end{array}$ & $\begin{array}{c}\text { Theatre } \\
\text { aggregate } \\
(4)\end{array}$ & $\begin{array}{c}\text { Concert } \\
\text { aggregate } \\
(5)\end{array}$ & $\begin{array}{c}\text { Theatre } \\
\text { aggregate } \\
(6)\end{array}$ \\
\hline & \multicolumn{6}{|c|}{ Panel A: Number of births } \\
\hline Log(Composer & $0.156^{* *}$ & 0.00342 & 0.0567 & 0.0145 & 0.119 & 0.0364 \\
\hline & $(0.0784)$ & $(0.0736)$ & $(0.0970)$ & $(0.0758)$ & $(0.112)$ & $(0.0874)$ \\
\hline Log(Value added pc) & $\begin{array}{c}1.550 \\
(0.952)\end{array}$ & $\begin{array}{c}0.803 \\
(0.549)\end{array}$ & $\begin{array}{l}2.648 * * \\
(0.957)\end{array}$ & $\begin{array}{c}0.520 \\
(0.437)\end{array}$ & $\begin{array}{c}2.899 * * \\
(1.203)\end{array}$ & $\begin{array}{l}0.961 * \\
(0.528)\end{array}$ \\
\hline Log(Population) & $\begin{array}{c}-0.0725 \\
(0.127)\end{array}$ & $\begin{array}{c}0.107 \\
(0.0984)\end{array}$ & $\begin{array}{c}1.422 * * * \\
(0.142)\end{array}$ & $\begin{array}{c}1.338 * * * \\
(0.0923)\end{array}$ & $\begin{array}{c}1.612 * * * \\
(0.189)\end{array}$ & $\begin{array}{c}1.369 * * * \\
(0.110)\end{array}$ \\
\hline $\begin{array}{l}\text { Share of educated } \\
\text { population } \\
\text { (in 2001) }\end{array}$ & $\begin{array}{c}4.283 \\
(3.541)\end{array}$ & $\begin{array}{c}3.928 \\
(2.306)\end{array}$ & $\begin{array}{c}1.421 \\
(2.997)\end{array}$ & $\begin{array}{l}4.880 * * \\
(2.048)\end{array}$ & $\begin{array}{l}-0.420 \\
(4.467)\end{array}$ & $\begin{array}{l}4.499 * \\
(2.200)\end{array}$ \\
\hline Region controls & yes & yes & yes & yes & yes & yes \\
\hline Observations & 102 & 102 & 102 & 102 & 102 & 102 \\
\hline \multirow[t]{2}{*}{ R-squared } & 0.621 & 0.652 & 0.847 & 0.933 & 0.825 & 0.934 \\
\hline & \multicolumn{6}{|c|}{ Panel B: Length of biographical entries } \\
\hline $\begin{array}{l}\text { Log(Length of } \\
\text { biographical entries) }\end{array}$ & $\begin{array}{l}0.159 * * \\
(0.069)\end{array}$ & $\begin{array}{c}0.0371 \\
(0.0562)\end{array}$ & $\begin{array}{c}0.0261 \\
(0.0842)\end{array}$ & $\begin{array}{c}0.0275 \\
(0.0556)\end{array}$ & $\begin{array}{l}0.0284 \\
(0.105)\end{array}$ & $\begin{array}{l}0.00173 \\
(0.0572)\end{array}$ \\
\hline Log(Value added pc) & $\begin{array}{c}1.270 \\
(1.053)\end{array}$ & $\begin{array}{c}0.835 \\
(0.541)\end{array}$ & $\begin{array}{c}2.607 * * \\
(0.985)\end{array}$ & $\begin{array}{c}0.574 \\
(0.435)\end{array}$ & $\begin{array}{c}2.893 * * \\
(1.218)\end{array}$ & $\begin{array}{l}0.974 * \\
(0.546)\end{array}$ \\
\hline Log(Population) & $\begin{array}{c}0.426 \\
(0.0348)\end{array}$ & $\begin{array}{c}0.118 \\
(0.0813)\end{array}$ & $\begin{array}{c}1.453 * * * \\
(0.107)\end{array}$ & $\begin{array}{l}1.341^{* * *} \\
(0.0680)\end{array}$ & $\begin{array}{c}1.693 * * * \\
(0.149)\end{array}$ & $\begin{array}{c}1.398 * * * \\
(0.0763)\end{array}$ \\
\hline $\begin{array}{l}\text { Share of educated } \\
\text { population } \\
\text { (in 2001) }\end{array}$ & $\begin{array}{c}5.327 \\
(4.501)\end{array}$ & $\begin{array}{l}3.8579 \\
(2.324)\end{array}$ & $\begin{array}{c}1.671 \\
(2.964)\end{array}$ & $\begin{array}{c}4.724 * * \\
(2.090)\end{array}$ & $\begin{array}{c}-0.0544 \\
(4.583)\end{array}$ & $\begin{array}{l}4.578 * \\
(2.224)\end{array}$ \\
\hline Region controls & yes & yes & yes & yes & yes & yes \\
\hline Observations & 102 & 102 & 102 & 102 & 102 & 102 \\
\hline R-squared & 0.631 & 0.623 & 0.847 & 0.933 & 0.822 & 0.933 \\
\hline
\end{tabular}

Note: Standard errors are clustered at the region level and reported in parentheses. The dependent variable measures the log number of performances per capita of a province (columns 1 and 2), log audience size (columns 3 and 4) or log box office income (columns 5 and 6) in each category of activities. 'Composer births' is a logged measure of the total number of composer births in a province that occurred during Renaissance (i.e. between 1400 and 1600). 'Length of biographical entries' is a logged measure of the total number of words written on composers born in a province during Renaissance. The database is recorded on the province level and the 2007 borders are utilised. $* * * * * / *$ indicate estimates that are significantly different from zero at 99/95/90\% confidence. 
Table 4. Historical composer births and contemporary supply of live performing arts. Disaggregated activities.

\begin{tabular}{|c|c|c|c|c|c|c|c|c|c|c|}
\hline & \multicolumn{10}{|c|}{ Log(Performances) } \\
\hline & \multicolumn{3}{|c|}{ Concert aggregate } & \multicolumn{7}{|c|}{ Theatre aggregate } \\
\hline & $\begin{array}{l}\text { Classical } \\
\text { concert } \\
(1) \\
\end{array}$ & $\begin{array}{c}\text { Jazz } \\
\text { concert } \\
(2) \\
\end{array}$ & $\begin{array}{c}\text { Pop } \\
\text { concert } \\
(3) \\
\end{array}$ & $\begin{array}{l}\text { Theatre } \\
\text { (4) }\end{array}$ & $\begin{array}{c}\text { Opera } \\
(5) \\
\end{array}$ & $\begin{array}{l}\text { Revue and } \\
\text { musical } \\
(6)\end{array}$ & $\begin{array}{l}\text { Ballet } \\
(7)\end{array}$ & $\begin{array}{l}\text { Puppets and } \\
\text { marionettes } \\
(8)\end{array}$ & $\begin{array}{l}\text { Performing } \\
\text { arts } \\
(9) \\
\end{array}$ & $\begin{array}{l}\text { Circus } \\
(10)\end{array}$ \\
\hline & \multicolumn{10}{|c|}{ Panel A: Number of births } \\
\hline births) & $\begin{array}{c}0.290^{* * *} \\
(0.0939)\end{array}$ & $\begin{array}{l}0.0805 \\
(0.148)\end{array}$ & $\begin{array}{c}-0.00803 \\
(0.119)\end{array}$ & $\begin{array}{c}0.0148 \\
(0.0807)\end{array}$ & $\begin{array}{l}0.157^{* *} \\
(0.0578)\end{array}$ & $\begin{array}{c}0.229 \\
(0.144)\end{array}$ & $\begin{array}{l}0.0641 \\
(0.109)\end{array}$ & $\begin{array}{l}0.0354 \\
(0.279)\end{array}$ & $\begin{array}{c}0.194 \\
(0.274)\end{array}$ & $\begin{array}{l}-0.0148 \\
(0.0807)\end{array}$ \\
\hline $\begin{array}{l}\log (\text { Value added } \\
\text { pc) }\end{array}$ & $\begin{array}{c}2.515 \\
(2.579)\end{array}$ & $\begin{array}{l}0.0105 \\
(1.546)\end{array}$ & $\begin{array}{c}1.574 \\
(1.195)\end{array}$ & $\begin{array}{c}0.786 \\
(0.864)\end{array}$ & $\begin{array}{l}-1.712 \\
(1.774)\end{array}$ & $\begin{array}{l}-0.0172 \\
(2.015)\end{array}$ & $\begin{array}{c}1.120 \\
(1.233)\end{array}$ & $\begin{array}{l}-2.541 \\
(2.717)\end{array}$ & $\begin{array}{c}3.650 \\
(4.024)\end{array}$ & $\begin{array}{c}0.786 \\
(0.864)\end{array}$ \\
\hline Log(Population) & $\begin{array}{c}0.263 \\
(0.588)\end{array}$ & $\begin{array}{l}-0.175 \\
(0.213)\end{array}$ & $\begin{array}{c}0.0472 \\
(0.0941)\end{array}$ & $\begin{array}{l}-0.0348 \\
(0.140)\end{array}$ & $\begin{array}{c}0.194 \\
(0.207)\end{array}$ & $\begin{array}{c}0.356^{* *} \\
(0.151)\end{array}$ & $\begin{array}{c}0.531 \\
(0.316)\end{array}$ & $\begin{array}{c}0.836 * * * \\
(0.275)\end{array}$ & $\begin{array}{l}0.343^{*} \\
(0.187)\end{array}$ & $\begin{array}{l}-0.0348 \\
(0.140)\end{array}$ \\
\hline $\begin{array}{l}\text { Share of educated } \\
\text { population } \\
\text { (in 2001) }\end{array}$ & $\begin{array}{l}-0.231 \\
(4.733)\end{array}$ & $\begin{array}{c}11.42 \\
(7.564)\end{array}$ & $\begin{array}{c}5.346 \\
(4.863)\end{array}$ & $\begin{array}{c}4.528 \\
(4.023)\end{array}$ & $\begin{array}{c}2.379 \\
(5.769)\end{array}$ & $\begin{array}{c}2.873 \\
(7.091)\end{array}$ & $\begin{array}{c}7.051 \\
(5.101)\end{array}$ & $\begin{array}{c}8.252 \\
(15.29)\end{array}$ & $\begin{array}{c}14.11 \\
(13.10)\end{array}$ & $\begin{array}{c}4.528 \\
(4.023)\end{array}$ \\
\hline Region controls & yes & yes & yes & yes & yes & yes & yes & yes & yes & yes \\
\hline Observations & 102 & 102 & 102 & 102 & 102 & 102 & 102 & 102 & 102 & 102 \\
\hline \multirow[t]{2}{*}{ R-squared } & 0.339 & 0.516 & 0.687 & 0.678 & 0.648 & 0.487 & 0.620 & 0.313 & 0.589 & 0.570 \\
\hline & \multicolumn{10}{|c|}{ Panel B: Length of biographical entries } \\
\hline $\begin{array}{l}\text { Log(Length of } \\
\text { biographical } \\
\text { entries) }\end{array}$ & $\begin{array}{c}0.288 * * * \\
(0.0793)\end{array}$ & $\begin{array}{l}0.148^{* *} \\
(0.0630)\end{array}$ & $\begin{array}{c}0.00496 \\
(0.111)\end{array}$ & $\begin{array}{l}0.154 * * * \\
(0.0498)\end{array}$ & $\begin{array}{l}0.256^{* *} \\
(0.0936)\end{array}$ & $\begin{array}{l}0.346^{*} \\
(0.179)\end{array}$ & $\begin{array}{c}0.0628 \\
(0.0990)\end{array}$ & $\begin{array}{l}-0.0487 \\
(0.167)\end{array}$ & $\begin{array}{l}0.0268 \\
(0.200)\end{array}$ & $\begin{array}{l}-0.0358 \\
(0.0981)\end{array}$ \\
\hline $\begin{array}{l}\text { Log(Value added } \\
\text { pc) }\end{array}$ & $\begin{array}{c}2.011 \\
(2.189)\end{array}$ & $\begin{array}{l}-0.0810 \\
(1.562)\end{array}$ & $\begin{array}{c}1.559 \\
(1.156)\end{array}$ & $\begin{array}{c}0.671 \\
(0.817)\end{array}$ & $\begin{array}{l}-1.822 \\
(1.891)\end{array}$ & $\begin{array}{c}-.022 \\
(2.063)\end{array}$ & $\begin{array}{c}1.230 \\
(1.243)\end{array}$ & $\begin{array}{l}-2.416 \\
(2.774)\end{array}$ & $\begin{array}{c}3.683 \\
(3.935)\end{array}$ & $\begin{array}{l}-1.098 \\
(0.912)\end{array}$ \\
\hline Log(Population) & $\begin{array}{c}0.405 \\
(0.488)\end{array}$ & $\begin{array}{l}-0.101 \\
(0.235)\end{array}$ & $\begin{array}{l}0.0284 \\
(0.107)\end{array}$ & $\begin{array}{c}0.313 \\
(0.315)\end{array}$ & $\begin{array}{c}0.660 \\
(0.302)\end{array}$ & $\begin{array}{c}0.992 \\
(0.250)\end{array}$ & $\begin{array}{l}0.317^{* *} \\
(0.132)\end{array}$ & $\begin{array}{c}0.116 \\
(0.0848)\end{array}$ & $\begin{array}{l}0.326^{*} \\
(0.178)\end{array}$ & $\begin{array}{l}0.927^{* *} \\
(0.386)\end{array}$ \\
\hline $\begin{array}{l}\text { Share of educated } \\
\text { population } \\
\text { (in 2001) }\end{array}$ & $\begin{array}{c}1.672 \\
(4.435)\end{array}$ & $\begin{array}{l}11.85 \\
(7.790)\end{array}$ & $\begin{array}{c}5.353 \\
(5.051)\end{array}$ & $\begin{array}{c}4.723 \\
(4.127)\end{array}$ & $\begin{array}{l}7.256 \\
(5.529)\end{array}$ & $\begin{array}{l}12.33^{*} \\
(7.071)\end{array}$ & $\begin{array}{c}6.634 \\
(5.192)\end{array}$ & $\begin{array}{c}8.097 \\
(15.35)\end{array}$ & $\begin{array}{c}14.62 \\
(13.30)\end{array}$ & $\begin{array}{c}0.546 \\
(5.410)\end{array}$ \\
\hline
\end{tabular}




\begin{tabular}{lcccccccccc} 
Region controls & yes & yes & yes & yes & yes & yes & yes & yes & yes & yes \\
Observations & 102 & 102 & 102 & 102 & 102 & 102 & 102 & 102 & 102 & 102 \\
R-squared & 0.361 & 0.515 & 0.687 & 0.681 & 0.590 & 0.334 & 0.621 & 0.313 & 0.585 & 0.570 \\
\hline
\end{tabular}

Note: Standard errors are clustered at the region level and reported in parentheses. The dependent variable measures the logged number of performances per capita of a province in each category of activities. See Table 3 for further details. 
Table 5. Historical composer births, classical concerts and opera. The number of performances, total attendance, and box office revenue.

\begin{tabular}{|c|c|c|c|c|c|c|}
\hline & \multicolumn{2}{|c|}{ Log(Performances) } & \multicolumn{2}{|c|}{ Log(Attendance) } & \multicolumn{2}{|c|}{ Log(Box office) } \\
\hline & $\begin{array}{l}\text { Classical } \\
\text { concert } \\
\text { (1) }\end{array}$ & $\begin{array}{l}\text { Opera } \\
(2)\end{array}$ & $\begin{array}{l}\text { Classical } \\
\text { concert } \\
\text { (3) }\end{array}$ & $\begin{array}{c}\text { Opera } \\
(1)\end{array}$ & $\begin{array}{l}\text { Classical } \\
\text { concert } \\
(2)\end{array}$ & $\begin{array}{c}\text { Opera } \\
(3)\end{array}$ \\
\hline & \multicolumn{6}{|c|}{ Panel A: Number of births } \\
\hline Log(Composer & $0.290 * * *$ & $0.157^{* *}$ & 0.157 & $0.415^{*}$ & $0.264^{* *}$ & $0.557^{*}$ \\
\hline & $(0.0939)$ & $(0.0578)$ & $(0.125)$ & $(0.230)$ & $(0.119)$ & $(0.319)$ \\
\hline $\log ($ Value added $p c)$ & $\begin{array}{l}2.515 \\
(2.579)\end{array}$ & $\begin{array}{l}-1.712 \\
(1.774)\end{array}$ & $\begin{array}{c}4.217 \\
(2.666)\end{array}$ & $\begin{array}{l}-5.208 \\
(4.839)\end{array}$ & $\begin{array}{c}3.966 \\
(2.532)\end{array}$ & $\begin{array}{l}-5.951 \\
(6.292)\end{array}$ \\
\hline Log(Population) & $\begin{array}{c}0.263 \\
(0.588)\end{array}$ & $\begin{array}{c}0.194 \\
(0.207)\end{array}$ & $\begin{array}{c}1.195 * * * \\
(0.155)\end{array}$ & $\begin{array}{c}2.399^{* * * *} \\
(0.606)\end{array}$ & $\begin{array}{c}1.308 * * * \\
(0.166)\end{array}$ & $\begin{array}{c}2.905 * * * \\
(0.779)\end{array}$ \\
\hline $\begin{array}{l}\text { Share of educated } \\
\text { population } \\
\text { (in 2001) }\end{array}$ & $\begin{array}{l}-0.231 \\
(4.733)\end{array}$ & $\begin{array}{l}2.379 \\
(5.769)\end{array}$ & $\begin{array}{l}4.246 \\
(4.803)\end{array}$ & $\begin{array}{l}10.82 \\
(9.556)\end{array}$ & $\begin{array}{l}5.488 \\
(6.239)\end{array}$ & $\begin{array}{l}15.01 \\
(11.67)\end{array}$ \\
\hline Region controls & yes & yes & yes & yes & yes & yes \\
\hline Observations & 102 & 102 & 102 & 102 & 102 & 102 \\
\hline \multirow[t]{2}{*}{ R-squared } & 0.339 & 0.648 & 0.705 & 0.658 & 0.743 & 0.642 \\
\hline & \multicolumn{6}{|c|}{ Panel B: Length of biographical entries } \\
\hline $\log ($ Length of & $0.288 * * *$ & $0.256^{* *}$ & $0.191 * * *$ & 0.126 & $0.290 * * *$ & 0.153 \\
\hline & $(0.0793)$ & $(0.0936)$ & $(0.0587)$ & $(0.176)$ & $(0.0877)$ & $(0.248)$ \\
\hline $\log ($ Value added $\mathrm{pc})$ & $\begin{array}{c}2.011 \\
(2.189)\end{array}$ & $\begin{array}{l}-1.822 \\
(1.891)\end{array}$ & $\begin{array}{c}3.853 \\
(2.487)\end{array}$ & $\begin{array}{l}-5.338 \\
(4.959)\end{array}$ & $\begin{array}{l}3.447 \\
(2.196)\end{array}$ & $\begin{array}{l}-6.024 \\
(6.472)\end{array}$ \\
\hline Log(Population) & $\begin{array}{c}0.405 \\
(0.488)\end{array}$ & $\begin{array}{c}0.660 \\
(0.302)\end{array}$ & $\begin{array}{c}1.214 * * * \\
(0.141)\end{array}$ & $\begin{array}{c}2.662^{* * * *} \\
(0.606)\end{array}$ & $\begin{array}{c}1.360^{* * * *} \\
(0.158)\end{array}$ & $\begin{array}{c}3.272 * * * \\
(0.759)\end{array}$ \\
\hline $\begin{array}{l}\text { Share of educated } \\
\text { population } \\
\text { (in 2001) }\end{array}$ & $\begin{array}{c}1.672 \\
(4.435)\end{array}$ & (5.529) & $\begin{array}{l}5.464 \\
(4.841)\end{array}$ & $\begin{array}{l}12.41 \\
(9.335)\end{array}$ & $\begin{array}{l}7.345 \\
(6.258)\end{array}$ & (11.77) \\
\hline Region controls & yes & yes & yes & yes & yes & yes \\
\hline Observations & 102 & 102 & 102 & 102 & 102 & 102 \\
\hline R-squared & 0.361 & 0.590 & 0.711 & 0.650 & 0.752 & 0.633 \\
\hline
\end{tabular}

Note: Standard errors are clustered at the region level and reported in parentheses. The dependent variable measures the logged number of performances per capita of a province (columns 1 and 2), logged total audience size (columns 3 and 4) and logged box office income (columns 5 and 6) in each category of activities. 'Composer births' is a logged measure of the total number of composer births in a province that occurred during Renaissance (i.e. between 1400 and 1600). 'Length of biographical entries' is a logged measure of the total number of words written on composers born in a province during Renaissance. The database is recorded on the province level and the 2007 borders are utilised. $* * * / * * / *$ indicate estimates that are significantly different from zero at $99 / 95 / 90 \%$ confidence. 
Table 6. Historical composer births and supply of other forms of entertainment.

\begin{tabular}{|c|c|c|c|c|c|c|c|c|c|c|c|c|c|}
\hline & \multicolumn{13}{|c|}{ Log(Performances) } \\
\hline & \multirow[b]{2}{*}{$\begin{array}{c}\text { Sports } \\
\text { activities } \\
(1) \\
\end{array}$} & \multicolumn{6}{|c|}{ Sports activities } & \multirow[b]{2}{*}{$\begin{array}{c}\text { Dance } \\
(8)\end{array}$} & \multirow[b]{2}{*}{$\begin{array}{c}\text { Concertinos } \\
(9) \\
\end{array}$} & \multirow[b]{2}{*}{$\begin{array}{c}\text { Touring } \\
\text { amusement } \\
(10) \\
\end{array}$} & \multirow[b]{2}{*}{$\begin{array}{c}\text { Exhibitions } \\
\text { and shows } \\
(11) \\
\end{array}$} & \multirow{2}{*}{$\begin{array}{l}\text { Multi- } \\
\text { genre } \\
\text { activities } \\
\text { supply } \\
\text { (12) }\end{array}$} & \multirow{2}{*}{$\begin{array}{c}\text { Cinema } \\
\text { (13) }\end{array}$} \\
\hline & & $\begin{array}{l}\text { Soccer } \\
\text { (2) }\end{array}$ & $\begin{array}{l}\text { Other } \\
\text { team } \\
(3)\end{array}$ & $\begin{array}{l}\text { Individual } \\
\text { sports } \\
\text { (4) }\end{array}$ & $\begin{array}{l}\text { Other } \\
\text { sports } \\
(5)\end{array}$ & $\begin{array}{l}\text { Bowling } \\
\text { (6) }\end{array}$ & $\begin{array}{l}\text { Go-kart } \\
\text { (7) }\end{array}$ & & & & & & \\
\hline \multicolumn{14}{|c|}{ Panel A: Number of births } \\
\hline $\begin{array}{l}\text { Log(Length of } \\
\text { biographical } \\
\text { entries) }\end{array}$ & $\begin{array}{l}-0.116^{*} \\
(0.066)\end{array}$ & $\begin{array}{l}-0.136 \\
(0.200)\end{array}$ & $\begin{array}{l}-0.117 \\
(0.195)\end{array}$ & $\begin{array}{l}-0.141 \\
(0.140)\end{array}$ & $\begin{array}{c}0.104 \\
(0.167)\end{array}$ & $\begin{array}{l}-0.107^{*} \\
(0.075)\end{array}$ & $\begin{array}{l}-0.459 \\
(0.332)\end{array}$ & $\begin{array}{l}-0.059^{*} \\
(0.029)\end{array}$ & $\begin{array}{l}-0.0603 \\
(0.0710)\end{array}$ & $\begin{array}{c}0.123 \\
(0.208)\end{array}$ & $\begin{array}{c}0.123 \\
(0.208)\end{array}$ & $\begin{array}{l}-0.0712 \\
(0.164)\end{array}$ & $\begin{array}{l}-0.00567 \\
(0.0762)\end{array}$ \\
\hline $\begin{array}{l}\text { Log(Value added } \\
\text { pc) }\end{array}$ & $\begin{array}{c}0.835 \\
(0.969)\end{array}$ & $\begin{array}{c}0.210 \\
(1.223)\end{array}$ & $\begin{array}{l}-0.0964 \\
(1.399)\end{array}$ & $\begin{array}{l}0.0598 \\
(2.342)\end{array}$ & $\begin{array}{l}-0.223 \\
(2.633)\end{array}$ & $\begin{array}{c}2.183 \\
(3.287)\end{array}$ & $\begin{array}{l}7.627 * * \\
(3.524)\end{array}$ & $\begin{array}{l}-1.619 \\
(4.813)\end{array}$ & $\begin{array}{l}0.0759 \\
(0.900)\end{array}$ & $\begin{array}{c}0.332 \\
(2.291)\end{array}$ & $\begin{array}{c}0.332 \\
(2.291)\end{array}$ & $\begin{array}{l}0.0225 \\
(2.028)\end{array}$ & $\begin{array}{c}0.801 \\
(0.565)\end{array}$ \\
\hline Log(Population) & $\begin{array}{l}0.0181 \\
(0.166)\end{array}$ & $\begin{array}{l}0.0613 \\
(0.299)\end{array}$ & $\begin{array}{l}0.0536 \\
(0.264)\end{array}$ & $\begin{array}{l}-0.0146 \\
(0.345)\end{array}$ & $\begin{array}{c}0.121 \\
(0.332)\end{array}$ & $\begin{array}{c}0.202 \\
(0.498)\end{array}$ & $\begin{array}{c}0.816 \\
(0.487)\end{array}$ & $\begin{array}{l}1.103 * \\
(0.552)\end{array}$ & $\begin{array}{l}0.0878 \\
(0.136)\end{array}$ & $\begin{array}{l}1.019 * * \\
(0.476)\end{array}$ & $\begin{array}{l}1.019 * * \\
(0.476)\end{array}$ & $\begin{array}{c}0.128 \\
(1.491)\end{array}$ & $\begin{array}{c}0.106 \\
(0.0984)\end{array}$ \\
\hline $\begin{array}{l}\text { Share of educated } \\
\text { population } \\
\text { (in 2001) }\end{array}$ & $\begin{array}{l}-0.263 \\
(1.714)\end{array}$ & $\begin{array}{l}-4.153 \\
(3.102)\end{array}$ & $\begin{array}{l}-3.717 \\
(3.345)\end{array}$ & $\begin{array}{l}2.273 \\
(6.723)\end{array}$ & $\begin{array}{l}4.425 \\
(10.55)\end{array}$ & $\begin{array}{l}-8.345 \\
(7.475)\end{array}$ & $\begin{array}{l}3.090 \\
(13.87)\end{array}$ & $\begin{array}{l}-8.052 \\
(18.36)\end{array}$ & $\begin{array}{l}1.558 \\
(4.497)\end{array}$ & $\begin{array}{l}-10.11 \\
(18.81)\end{array}$ & $\begin{array}{l}-10.11 \\
(8.266)\end{array}$ & $\begin{array}{r}4.713 \\
(8.516)\end{array}$ & $\begin{array}{l}4.862 * \\
(2.419)\end{array}$ \\
\hline $\begin{array}{l}\text { Region controls } \\
\text { Observations } \\
\text { R-squared }\end{array}$ & $\begin{array}{c}\text { yes } \\
102 \\
0.692\end{array}$ & $\begin{array}{c}\text { yes } \\
102 \\
0.733\end{array}$ & $\begin{array}{c}\text { yes } \\
102 \\
0.437\end{array}$ & $\begin{array}{c}\text { yes } \\
102 \\
0.604\end{array}$ & $\begin{array}{c}\text { yes } \\
102 \\
0.488\end{array}$ & $\begin{array}{c}\text { yes } \\
102 \\
0.417\end{array}$ & $\begin{array}{c}\text { yes } \\
102 \\
0.231\end{array}$ & $\begin{array}{c}\text { yes } \\
102 \\
0.703\end{array}$ & $\begin{array}{c}\text { yes } \\
102 \\
0.671\end{array}$ & $\begin{array}{c}\text { yes } \\
102 \\
0.288\end{array}$ & $\begin{array}{c}\text { yes } \\
102 \\
0.544\end{array}$ & $\begin{array}{c}\text { yes } \\
102 \\
0.678\end{array}$ & $\begin{array}{c}\text { yes } \\
102 \\
0.617\end{array}$ \\
\hline \multicolumn{14}{|c|}{ Panel B: Length of biographical entries } \\
\hline $\begin{array}{l}\text { Log(Length of } \\
\text { biographical } \\
\text { entries) }\end{array}$ & $\begin{array}{l}-0.0844 \\
(0.0883)\end{array}$ & $\begin{array}{l}-0.141 \\
(0.184)\end{array}$ & $\begin{array}{l}-0.129 \\
(0.171)\end{array}$ & $\begin{array}{l}-0.142 \\
(0.170)\end{array}$ & $\begin{array}{l}-0.0576 \\
(0.199)\end{array}$ & $\begin{array}{c}-0.123^{* *} \\
(0.054)\end{array}$ & $\begin{array}{l}-0.316 \\
(0.309)\end{array}$ & $\begin{array}{c}-0.184 \\
(0.319)\end{array}$ & $\begin{array}{l}-0.0732 \\
(0.0622)\end{array}$ & $\begin{array}{l}-0.0541 \\
(0.102)\end{array}$ & $\begin{array}{c}0.260 \\
(0.490)\end{array}$ & $\begin{array}{l}-0.0115 \\
(0.172)\end{array}$ & $\begin{array}{l}-0.0269 \\
(0.0584)\end{array}$ \\
\hline $\begin{array}{l}\text { Log(Value added } \\
\text { pc) }\end{array}$ & $\begin{array}{c}0.967 \\
(1.019)\end{array}$ & $\begin{array}{c}0.460 \\
(1.376)\end{array}$ & $\begin{array}{c}0.135 \\
(1.613)\end{array}$ & $\begin{array}{c}0.310 \\
(2.183)\end{array}$ & $\begin{array}{l}-0.0445 \\
(2.693)\end{array}$ & $\begin{array}{c}2.101 \\
(3.216)\end{array}$ & $\begin{array}{l}8.112 * * \\
(3.204)\end{array}$ & $\begin{array}{l}-1.497 \\
(5.214)\end{array}$ & $\begin{array}{c}0.210 \\
(0.908)\end{array}$ & $\begin{array}{c}0.808 \\
(0.918)\end{array}$ & $\begin{array}{l}-3.656 \\
(3.905)\end{array}$ & $\begin{array}{c}0.417 \\
(2.184)\end{array}$ & $\begin{array}{c}0.859 \\
(0.552)\end{array}$ \\
\hline Log(Population) & $\begin{array}{c}-0.0286 \\
(0.148)\end{array}$ & $\begin{array}{l}0.0302 \\
(0.253)\end{array}$ & $\begin{array}{l}0.0312 \\
(0.216)\end{array}$ & $\begin{array}{l}-0.0491 \\
(0.339)\end{array}$ & $\begin{array}{c}0.238 \\
(0.346)\end{array}$ & $\begin{array}{c}0.107 \\
(0.478)\end{array}$ & $\begin{array}{c}0.620 \\
(0.458)\end{array}$ & $\begin{array}{c}0.721 \\
(0.507)\end{array}$ & $\begin{array}{c}0.0798 \\
(0.120)\end{array}$ & $\begin{array}{l}0.0510 \\
(0.150)\end{array}$ & $\begin{array}{c}0.621 \\
(0.683)\end{array}$ & $\begin{array}{l}1.125 * * \\
(0.440)\end{array}$ & $\begin{array}{c}0.116 \\
(0.0848)\end{array}$ \\
\hline $\begin{array}{l}\text { Share of educated } \\
\text { population } \\
\text { (in 2001) }\end{array}$ & $\begin{array}{l}-0.880 \\
(2.011)\end{array}$ & $\begin{array}{l}-5.072 \\
(4.011)\end{array}$ & $\begin{array}{l}-4.542 \\
(4.291)\end{array}$ & $\begin{array}{c}1.339 \\
(6.378)\end{array}$ & $\begin{array}{l}4.364 \\
(10.41)\end{array}$ & $\begin{array}{l}-8.494 \\
(6.966)\end{array}$ & $\begin{array}{c}0.726 \\
(13.79)\end{array}$ & $\begin{array}{l}-10.07 \\
(19.05)\end{array}$ & $\begin{array}{c}1.101 \\
(4.461)\end{array}$ & $\begin{array}{l}5.562 * \\
(3.089)\end{array}$ & $\begin{array}{c}12.21 \\
(19.43)\end{array}$ & $\begin{array}{l}-9.922 \\
(8.551)\end{array}$ & $\begin{array}{l}4.726 * \\
(2.438)\end{array}$ \\
\hline $\begin{array}{l}\text { Region controls } \\
\text { Observations }\end{array}$ & $\begin{array}{l}\text { yes } \\
102\end{array}$ & $\begin{array}{l}\text { yes } \\
102\end{array}$ & $\begin{array}{l}\text { yes } \\
102\end{array}$ & $\begin{array}{l}\text { yes } \\
102\end{array}$ & $\begin{array}{l}\text { yes } \\
102\end{array}$ & $\begin{array}{l}\text { yes } \\
102\end{array}$ & $\begin{array}{l}\text { yes } \\
102\end{array}$ & $\begin{array}{l}\text { yes } \\
102\end{array}$ & $\begin{array}{l}\text { yes } \\
102\end{array}$ & $\begin{array}{l}\text { yes } \\
102\end{array}$ & $\begin{array}{l}\text { yes } \\
102\end{array}$ & $\begin{array}{l}\text { yes } \\
102\end{array}$ & $\begin{array}{l}\text { yes } \\
102\end{array}$ \\
\hline
\end{tabular}


R-squared 0.723

0.695

0.736

0.439

0.603

0.486

0.412

0.212

0.706

0.673

0.289

0.542

0.617

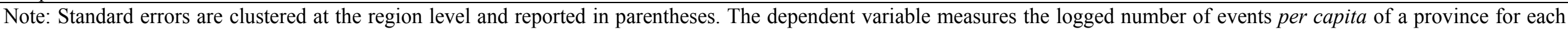

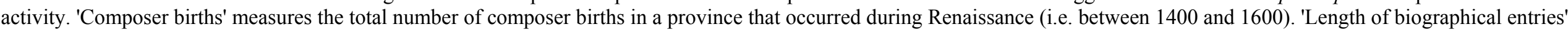

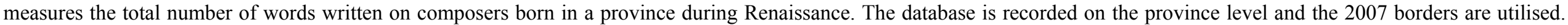
$* * * / * * / *$ indicate estimates that are significantly different from zero at $99 / 95 / 90 \%$ confidence. 
Table 7. Timing of the persistency.

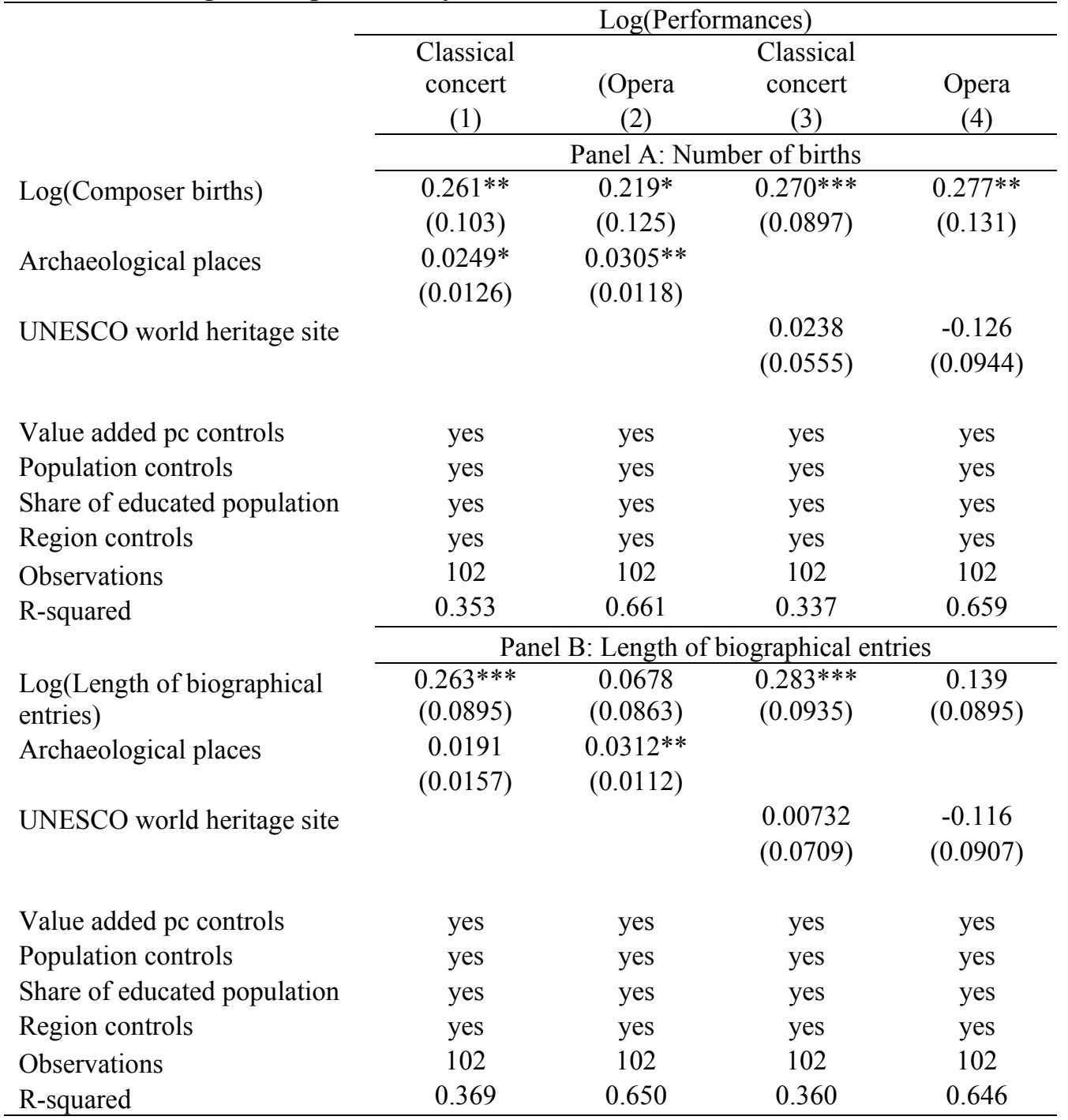

Note: Standard errors are clustered at the region level and reported in parentheses. The dependent variable measures the logged number of performances per capita of a province. $* * * / * * / *$ indicate estimates that are significantly different from zero at $99 / 95 / 90 \%$ confidence. See Table 5 for further details. 
Table 8. Correlation matrix of composer births in a province by century.

\begin{tabular}{lccccccc}
\hline & 14 th & 15 th & 16th & 17 th & 18th & 19th & 20th \\
\cline { 2 - 7 } 14 th & 1.000 & & & & & & \\
15 th & $0.608^{*}$ & 1.000 & & & & & \\
16 th & $0.268^{*}$ & $0.659^{*}$ & 1.000 & & & & \\
17 th & 0.106 & $0.466^{*}$ & $0.860^{*}$ & 1.000 & & & \\
18 th & 0.164 & $0.444^{*}$ & $0.793^{*}$ & $0.826^{*}$ & 1.000 & & \\
19 th & 0.109 & $0.369^{*}$ & $0.702^{*}$ & $0.731^{*}$ & $0.803^{*}$ & 1.000 & \\
20th & 0.098 & $0.275^{*}$ & $0.582^{*}$ & $0.755^{*}$ & $0.639^{*}$ & $0.752^{*}$ & 1.000
\end{tabular}

Note: $*$ denotes correlation coefficients significant at the $5 \%$ confidence level. 
Table 9. Geographic persistency of composer births.

\begin{tabular}{lcccc}
\hline & \multicolumn{5}{c}{ Composer births } \\
& $(1)$ & $(2)$ & $(3)$ & $(4)$ \\
\cline { 2 - 5 } $\begin{array}{l}\text { Composer births } \\
\text { (previous century) }\end{array}$ & $0.715^{* * *}$ & $0.733^{* * *}$ & $0.280 * * *$ & $0.297 * * *$ \\
& $(0.0290)$ & $(0.0290)$ & $(0.0377)$ & $(0.0386)$ \\
Century fixed effects & & & & \\
Province fixed effects & & yes & & yes \\
Observations & 642 & 642 & 642 & yes \\
R-squared & 0.094 & 0.100 & 0.094 & 0.100 \\
\hline
\end{tabular}

Note: Standard errors are reported in parentheses. The dependent variable measures the number of composer births in a province in century $(c)$. The reported explanatory variable measures the number of composer births in a province in the previous century $(c-1)$. The data is based on observations for 107 provinces and seven centuries (14th to 20 th). $* * * / * * / *$ indicate estimates that are significantly different from zero at $99 / 95 / 90 \%$ confidence. 


\section{Figures}

Figure 1. Composer births in Italy in 1400-1600.

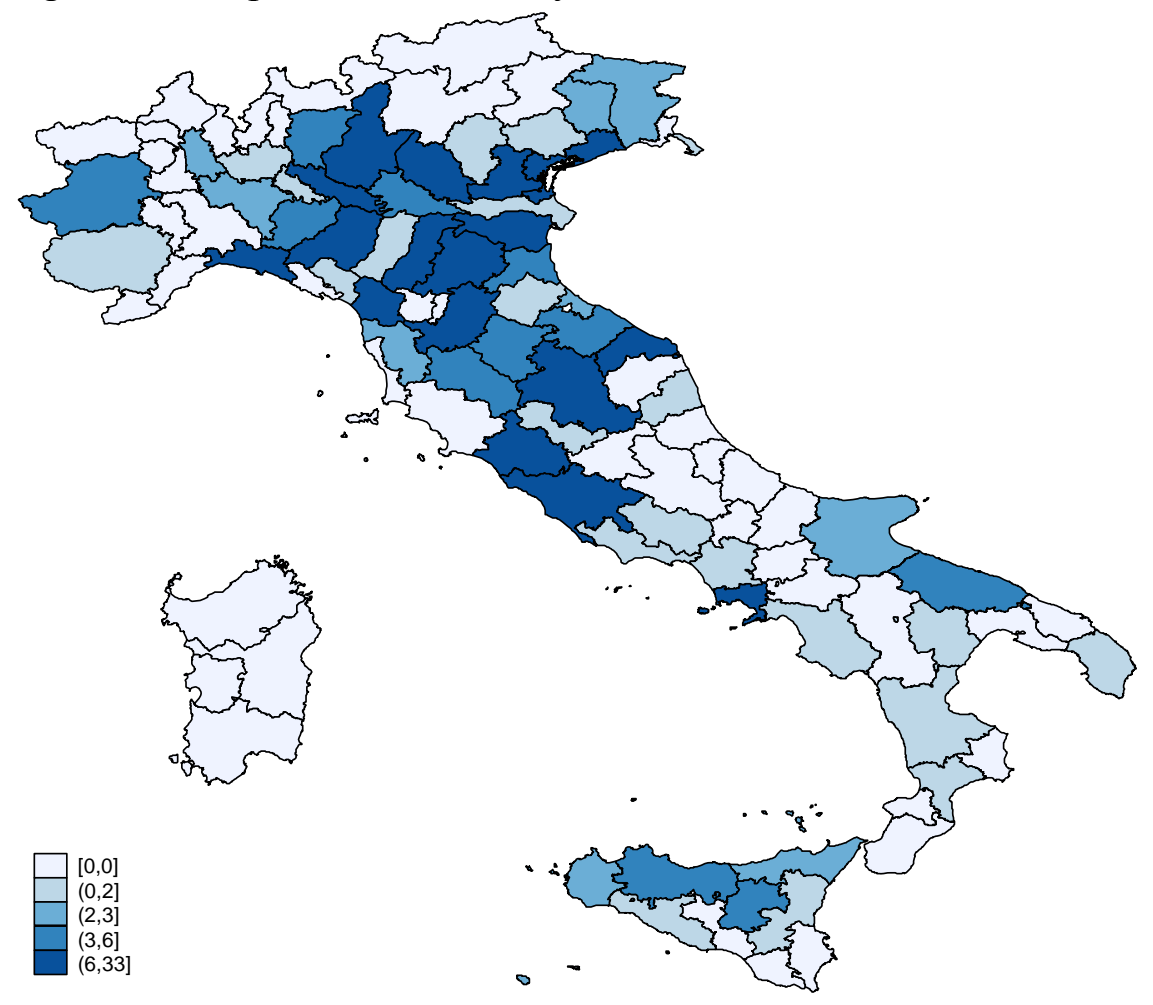

Sources: See text. 
Figure 2. Concert and theatre performances in Italy in 2007.

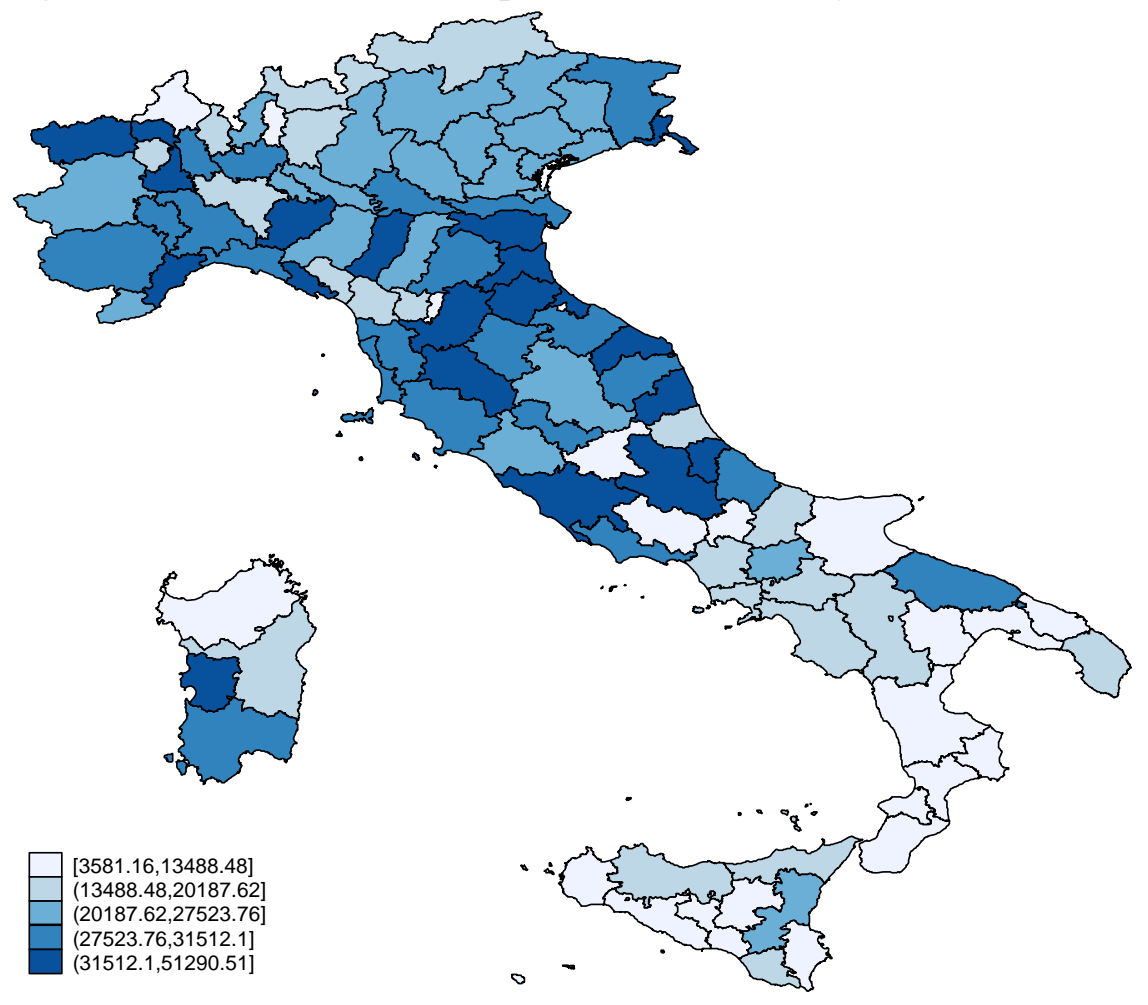

Sources: See text. 


\section{Online Appendix}

Appendix 1. Specification of data extraction software.

In order to automatically extract and process information from Grove Music Online, a purpose-built java application is utilised. The software conducts a search for all composers stored in the source dictionary. For all the results (composer entries) it identifies the related stored web pages, in order to extract their content. The processing done on the set of web pages comprising each composer's life was threefold. First, key elements such as the full name, place of birth, place of death, birth date, death date, nationality and list of occupations were extracted. ${ }^{21}$ Second, a word count for all the sections - that is life, works, bibliography and writings - in the result pages was calculated. This calculation takes into account the fact that a section may consist of several web pages. Third, each entry was scanned to count the occurrence of predefined terms in several categories, such as, for example, music instruments or types of works. All the search results are stored in order to allow further investigation of the data.

\footnotetext{
${ }^{21}$ Based on the nationality variable composers who are listed as 'Italian' are identified and chosen as the underlying sample for this research.
} 
Appendix 2. Extended Summary Statistics.

Table A2. Extended Summary Statistics.

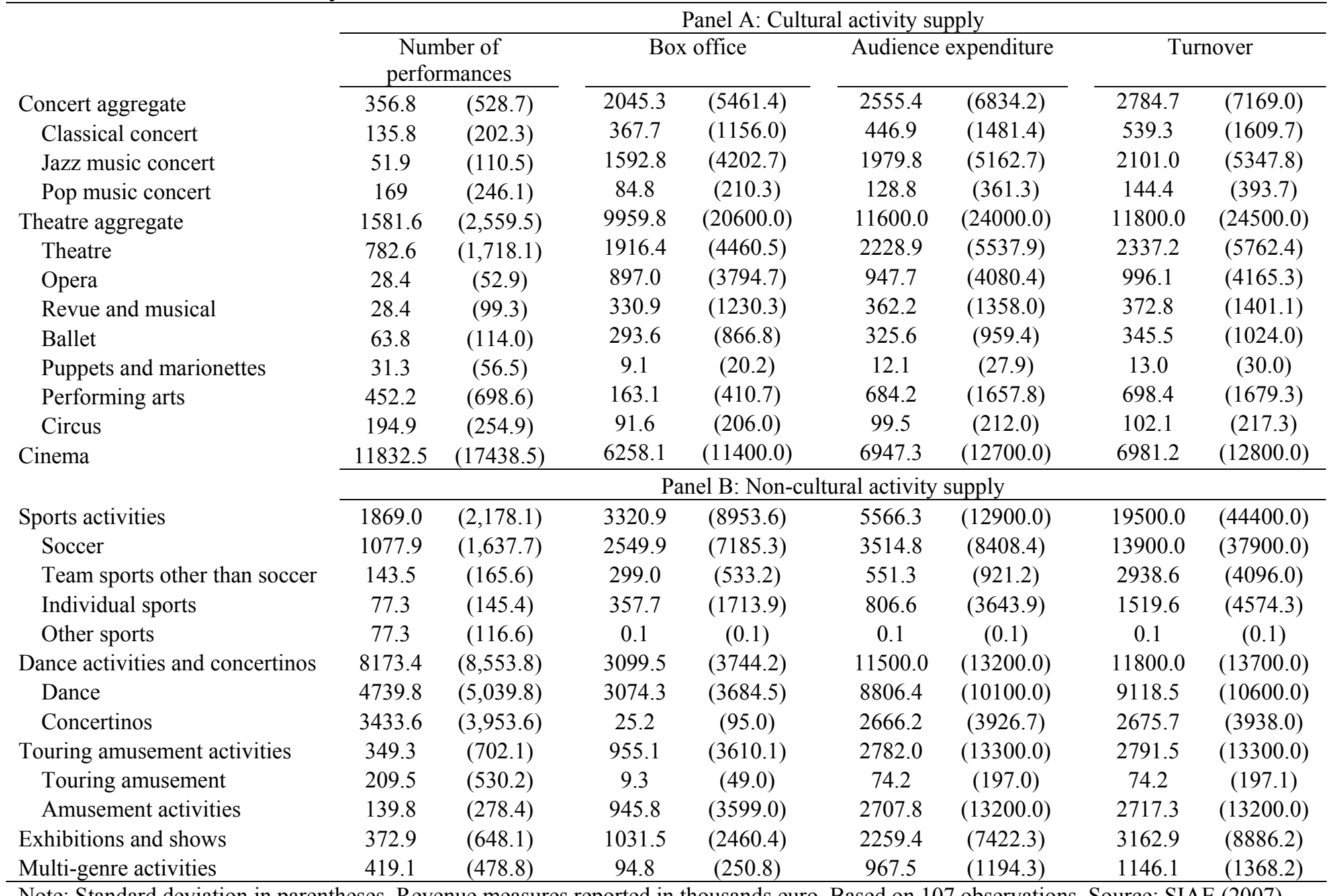

Note: Standard deviation in parentheses. Revenue measures reported in thousands euro. Based on 107 observations. Source: SIAE (2007). 
Appendix 3. Historical cultural activity and revenues of cultural institutions.

Here it is shown that the results remain consistent across all three types of revenue measures.

Table A3 shows the results for the baseline revenue measure box office (columns 1 and 2), which is complemented by audience expenditure ( 3 and 4 ) and turnover (5 and 6). ${ }^{22}$ The coefficients remain consistent in sign, significance and even size, for each of the three dependent variables.

Table A3. Historical composer births and revenues (box office, audience expenditure and turnover).

\begin{tabular}{|c|c|c|c|c|c|c|}
\hline & \multicolumn{4}{|c|}{$\begin{array}{l}\text { Log(Audience } \\
\text { expenditure) }\end{array}$} & \multicolumn{2}{|c|}{ Log(Turnover) } \\
\hline & $\begin{array}{l}\text { Classical } \\
\text { concert } \\
(1)\end{array}$ & $\begin{array}{l}\text { Opera } \\
(2)\end{array}$ & $\begin{array}{l}\text { Classical } \\
\text { concert } \\
(3)\end{array}$ & $\begin{array}{c}\text { Opera } \\
(4)\end{array}$ & $\begin{array}{l}\text { Classical } \\
\text { concert } \\
(5)\end{array}$ & $\begin{array}{c}\text { Opera } \\
(6)\end{array}$ \\
\hline & \multicolumn{6}{|c|}{ Panel A: Number of births } \\
\hline \multirow{2}{*}{$\begin{array}{l}\text { Log(Composer } \\
\text { births) }\end{array}$} & $0.264 * *$ & $0.557^{*}$ & $0.305 * * *$ & 0.520 & $0.267 * *$ & 0.516 \\
\hline & $(0.119)$ & $(0.319)$ & $(0.103)$ & $(0.307)$ & $(0.109)$ & $(0.308)$ \\
\hline \multirow[t]{2}{*}{ Log(Value added pc) } & 3.966 & -5.951 & $3.558^{*}$ & -2.352 & $3.757^{*}$ & -2.796 \\
\hline & $(2.532)$ & $(6.292)$ & $(1.735)$ & $(3.379)$ & $(1.849)$ & $(3.505)$ \\
\hline \multirow[t]{2}{*}{ Log(Population) } & $1.308 * * *$ & $2.905 * * *$ & $1.213 * * *$ & $2.674 * * *$ & $1.232 * * *$ & $2.736 * * *$ \\
\hline & $(0.166)$ & $(0.779)$ & $(0.202)$ & $(0.639)$ & $(0.214)$ & $(0.643)$ \\
\hline \multirow{2}{*}{$\begin{array}{l}\text { Share of educated } \\
\text { population } \\
\text { (in 2001) }\end{array}$} & 5.488 & 15.01 & 4.832 & 3.872 & 4.813 & 3.608 \\
\hline & $(6.239)$ & $(11.67)$ & $(6.368)$ & $(14.52)$ & $(6.399)$ & $(13.95)$ \\
\hline Region controls & yes & yes & yes & yes & yes & yes \\
\hline Observations & 102 & 102 & 102 & 102 & 102 & 102 \\
\hline \multirow[t]{2}{*}{ R-squared } & 0.743 & 0.642 & 0.742 & 0.647 & 0.740 & 0.649 \\
\hline & \multicolumn{6}{|c|}{ Panel B: Length of biographical entries } \\
\hline \multirow{2}{*}{$\begin{array}{l}\text { Log(Length of } \\
\text { biographical entries) }\end{array}$} & $0.290 * * *$ & 0.153 & $0.306^{* * *}$ & 0.139 & $0.262^{*}$ & 0.125 \\
\hline & $(0.0877)$ & $(0.248)$ & $(0.102)$ & $(0.244)$ & $(0.130)$ & $(0.242)$ \\
\hline \multirow[t]{2}{*}{ Log(Value added pc) } & 3.447 & -6.024 & $2.989 * *$ & -2.511 & $3.271 * *$ & -2.926 \\
\hline & $(2.196)$ & $(6.472)$ & $(1.370)$ & $(3.481)$ & $(1.498)$ & $(3.576)$ \\
\hline \multirow[t]{2}{*}{ Log(Population) } & $1.360 * * *$ & $3.272 * * *$ & $1.286^{* * *}$ & $3.009 * * *$ & $1.300 * * *$ & $3.075 * * *$ \\
\hline & $(0.158)$ & $(0.759)$ & $(0.191)$ & $(0.596)$ & $(0.203)$ & $(0.600)$ \\
\hline $\begin{array}{l}\text { Share of educated } \\
\text { population }\end{array}$ & 7.345 & 16.82 & 6.905 & 5.712 & 6.604 & 5.380 \\
\hline (in 2001) & $(6.258)$ & $(11.77)$ & $(6.130)$ & $(14.21)$ & $(6.147)$ & (13.66) \\
\hline Region controls & yes & yes & yes & yes & yes & yes \\
\hline Observations & 102 & 102 & 102 & 102 & 102 & 102 \\
\hline R-squared & 0.752 & 0.633 & 0.750 & 0.639 & 0.745 & 0.641 \\
\hline
\end{tabular}

Note: Standard errors are clustered at the region level and reported in parentheses. $* * * / * * *$ indicate estimates that are significantly different from zero at 99/95/90\% confidence.

\footnotetext{
${ }^{22}$ See the subsection 'Data sources' for a description of each variable and Table A2 in Appendix 2 for a summary.
} 
Appendix 4. Measuring contemporary entertainment activity: total attendance and box office revenues.

Table A4.1. Historical composer births and contemporary supply of live performing arts: Total attendance.

\begin{tabular}{|c|c|c|c|c|c|c|c|c|c|c|}
\hline & \multicolumn{10}{|c|}{ Log(Attendance) } \\
\hline & \multicolumn{3}{|c|}{ Concert aggregate } & \multicolumn{7}{|c|}{ Theatre aggregate } \\
\hline & $\begin{array}{c}\text { Classical } \\
\text { concert } \\
(1) \\
\end{array}$ & $\begin{array}{c}\text { Jazz } \\
\text { concert } \\
(2) \\
\end{array}$ & $\begin{array}{c}\text { Pop } \\
\text { concert } \\
(3)\end{array}$ & $\begin{array}{c}\text { Theatre } \\
\text { (4) }\end{array}$ & $\begin{array}{l}\text { Opera } \\
(5) \\
\end{array}$ & $\begin{array}{c}\text { Revue and } \\
\text { musical } \\
(6)\end{array}$ & $\begin{array}{c}\text { Ballet } \\
(7)\end{array}$ & $\begin{array}{c}\text { Puppets and } \\
\text { marionettes } \\
(8)\end{array}$ & $\begin{array}{l}\text { Performing } \\
\text { arts } \\
(9) \\
\end{array}$ & $\begin{array}{l}\text { Circus } \\
(10) \\
\end{array}$ \\
\hline & \multicolumn{10}{|c|}{ Panel A: Number of births } \\
\hline $\log$ (Composer births) & $\begin{array}{c}0.157 \\
(0.125)\end{array}$ & $\begin{array}{l}-0.0542 \\
(0.229)\end{array}$ & $\begin{array}{c}-0.0490 \\
(0.128)\end{array}$ & $\begin{array}{l}-0.0193 \\
(0.0750)\end{array}$ & $\begin{array}{l}0.415^{*} \\
(0.230)\end{array}$ & $\begin{array}{c}0.208 \\
(0.284)\end{array}$ & $\begin{array}{c}-0.0170 \\
(0.152)\end{array}$ & $\begin{array}{c}0.560 \\
(0.376)\end{array}$ & $\begin{array}{c}0.419 \\
(0.320)\end{array}$ & $\begin{array}{c}0.118 \\
(0.179)\end{array}$ \\
\hline Log(Value added pc) & $\begin{array}{c}4.217 \\
(2.666)\end{array}$ & $\begin{array}{l}-1.934 \\
(3.082)\end{array}$ & $\begin{array}{c}2.871 * * * \\
(0.866)\end{array}$ & $\begin{array}{c}0.926 \\
(0.598)\end{array}$ & $\begin{array}{l}-5.208 \\
(4.839)\end{array}$ & $\begin{array}{l}-2.190 \\
(4.495)\end{array}$ & $\begin{array}{c}1.631 \\
(1.556)\end{array}$ & $\begin{array}{l}-4.057 \\
(3.889)\end{array}$ & $\begin{array}{l}-0.340 \\
(4.254)\end{array}$ & $\begin{array}{l}-1.235 \\
(0.928)\end{array}$ \\
\hline Log(Population) & $\begin{array}{c}1.195 * * * \\
(0.155)\end{array}$ & $\begin{array}{c}2.174 * * * \\
(0.641)\end{array}$ & $\begin{array}{c}1.682 * * * \\
(0.287)\end{array}$ & $\begin{array}{c}1.491 * * * \\
(0.113)\end{array}$ & $\begin{array}{c}2.399 * * * \\
(0.606)\end{array}$ & $\begin{array}{c}3.249 * * * \\
(0.651)\end{array}$ & $\begin{array}{c}1.569 * * * \\
(0.310)\end{array}$ & $\begin{array}{c}2.399 * * * \\
(0.816)\end{array}$ & $\begin{array}{c}2.150 * * \\
(0.756)\end{array}$ & $\begin{array}{c}1.194 * * * \\
(0.112)\end{array}$ \\
\hline $\begin{array}{l}\text { Share of educated } \\
\text { population } \\
\text { (in 2001) }\end{array}$ & $\begin{array}{c}4.246 \\
(4.803)\end{array}$ & $\begin{array}{c}11.17 \\
(9.169)\end{array}$ & $\begin{array}{l}-1.536 \\
(4.418)\end{array}$ & $\begin{array}{c}4.162 \\
(2.541)\end{array}$ & $\begin{array}{c}10.82 \\
(9.556)\end{array}$ & $\begin{array}{c}14.24 \\
(14.05)\end{array}$ & $\begin{array}{c}8.954 \\
(6.101)\end{array}$ & $\begin{array}{c}8.659 \\
(16.82)\end{array}$ & $\begin{array}{c}11.11 \\
(17.13)\end{array}$ & $\begin{array}{c}13.04 \\
(10.60)\end{array}$ \\
\hline Region controls & yes & yes & yes & yes & yes & yes & yes & yes & yes & yes \\
\hline Observations & 102 & 102 & 102 & 102 & 102 & 102 & 102 & 102 & 102 & 102 \\
\hline \multirow[t]{2}{*}{ R-squared } & 0.705 & 0.679 & 0.692 & 0.928 & 0.658 & 0.598 & 0.717 & 0.596 & 0.537 & 0.633 \\
\hline & \multicolumn{10}{|c|}{ Panel B: Length of biographical entries } \\
\hline $\begin{array}{l}\text { Log(Length of } \\
\text { biographical entries) }\end{array}$ & $0.191 * * *$ & -0.187 & -0.113 & 0.0240 & 0.126 & -0.0596 & -0.0684 & 0.374 & 0.129 & 0.0819 \\
\hline & $(0.0587)$ & $(0.186)$ & $(0.132)$ & $(0.0616)$ & $(0.176)$ & $(0.309)$ & $(0.151)$ & $(0.399)$ & $(0.318)$ & $(0.131)$ \\
\hline Log(Value added pc) & $\begin{array}{c}3.853 \\
(2.487)\end{array}$ & $\begin{array}{l}-1.551 \\
(3.080)\end{array}$ & $\begin{array}{c}3.097 * * * \\
(0.899)\end{array}$ & $\begin{array}{c}0.870 \\
(0.577)\end{array}$ & $\begin{array}{l}-5.338 \\
(4.959)\end{array}$ & $\begin{array}{l}-2.004 \\
(4.433)\end{array}$ & $\begin{array}{c}1.771 \\
(1.500)\end{array}$ & $\begin{array}{l}-4.704 \\
(3.782)\end{array}$ & $\begin{array}{l}-0.505 \\
(4.258)\end{array}$ & $\begin{array}{l}-1.378 \\
(1.051)\end{array}$ \\
\hline Log(Population) & $\begin{array}{c}1.214 * * * \\
(0.141)\end{array}$ & $\begin{array}{c}2.234 * * * \\
(0.663)\end{array}$ & $\begin{array}{c}1.705 * * * \\
(0.269)\end{array}$ & $\begin{array}{c}1.463 * * * \\
(0.0962)\end{array}$ & $\begin{array}{c}2.662 * * * \\
(0.606)\end{array}$ & $\begin{array}{c}3.447 * * * \\
(0.627)\end{array}$ & $\begin{array}{c}1.593 * * * \\
(0.305)\end{array}$ & $\begin{array}{c}2.637 * * * \\
(0.789)\end{array}$ & $\begin{array}{c}2.410 * * * \\
(0.731)\end{array}$ & $\begin{array}{c}1.243 * * * \\
(0.153)\end{array}$ \\
\hline $\begin{array}{l}\text { Share of educated } \\
\text { population } \\
\text { (in 2001) }\end{array}$ & $\begin{array}{c}5.464 \\
(4.841)\end{array}$ & $\begin{array}{c}10.22 \\
(9.378)\end{array}$ & $\begin{array}{l}-2.151 \\
(4.560)\end{array}$ & $\begin{array}{c}4.223 \\
(2.549)\end{array}$ & $\begin{array}{c}12.41 \\
(9.335)\end{array}$ & $\begin{array}{c}14.45 \\
(14.16)\end{array}$ & $\begin{array}{c}8.612 \\
(5.856)\end{array}$ & $\begin{array}{c}11.64 \\
(18.31)\end{array}$ & $\begin{array}{c}12.67 \\
(17.84)\end{array}$ & $\begin{array}{c}13.68 \\
(10.23)\end{array}$ \\
\hline Region controls & yes & yes & yes & yes & yes & yes & yes & yes & yes & yes \\
\hline Observations & 102 & 102 & 102 & 102 & 102 & 102 & 102 & 102 & 102 & 102 \\
\hline R-squared & 0.711 & 0.684 & 0.695 & 0.928 & 0.650 & 0.597 & 0.718 & 0.591 & 0.529 & 0.632 \\
\hline
\end{tabular}


category of activities. See Table 3 for further details. 
Table A4.2. Historical composer births and contemporary supply of live performing arts: Total box office.

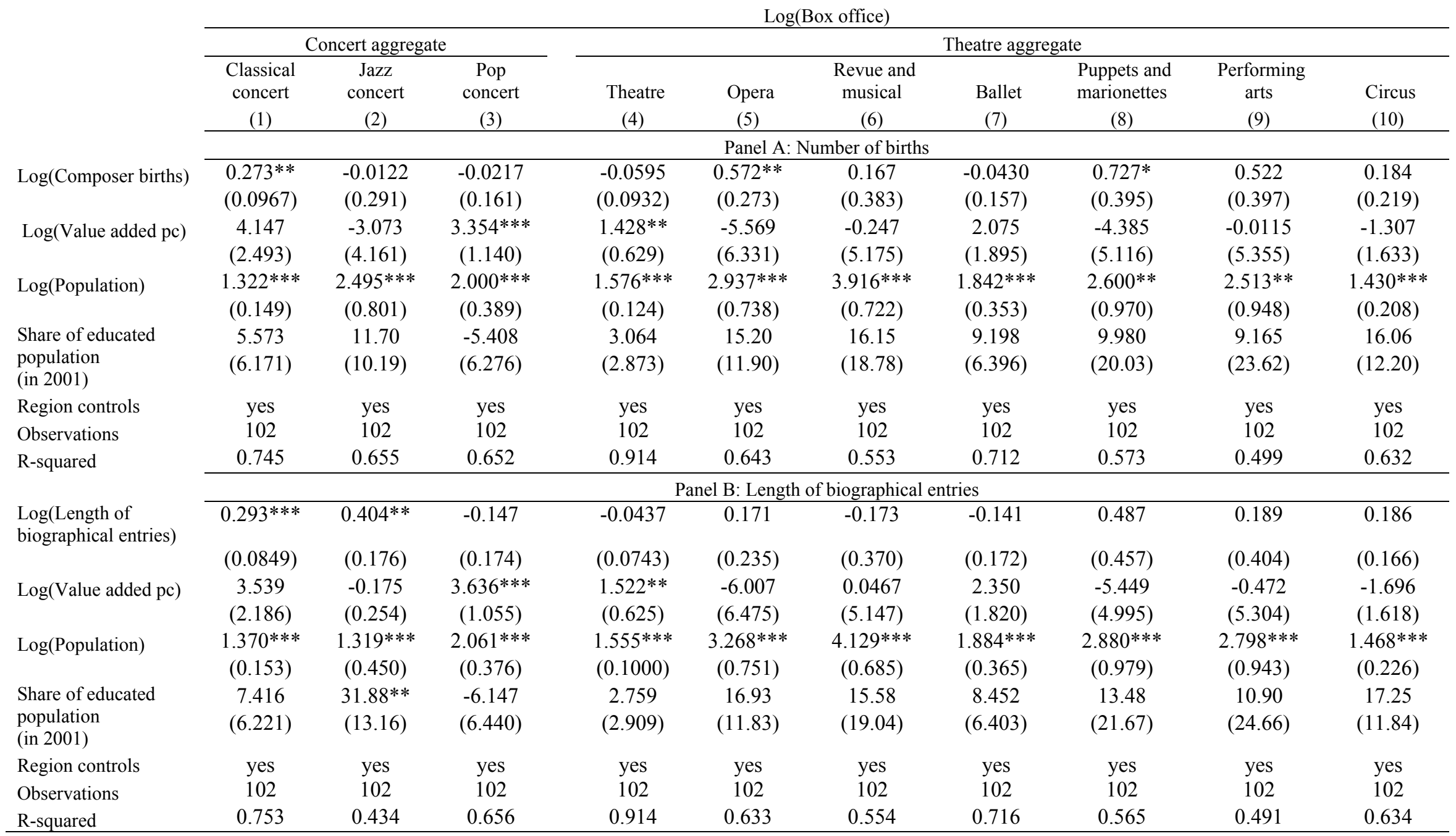

Note: Standard errors are clustered at the region level and reported in parentheses. The dependent variable measures the logged number of total box office revenues of a province for each activity. See Table 3 for further details. 
Table A4.3. Historical composer births and supply of other forms of entertainment: Total attendance.

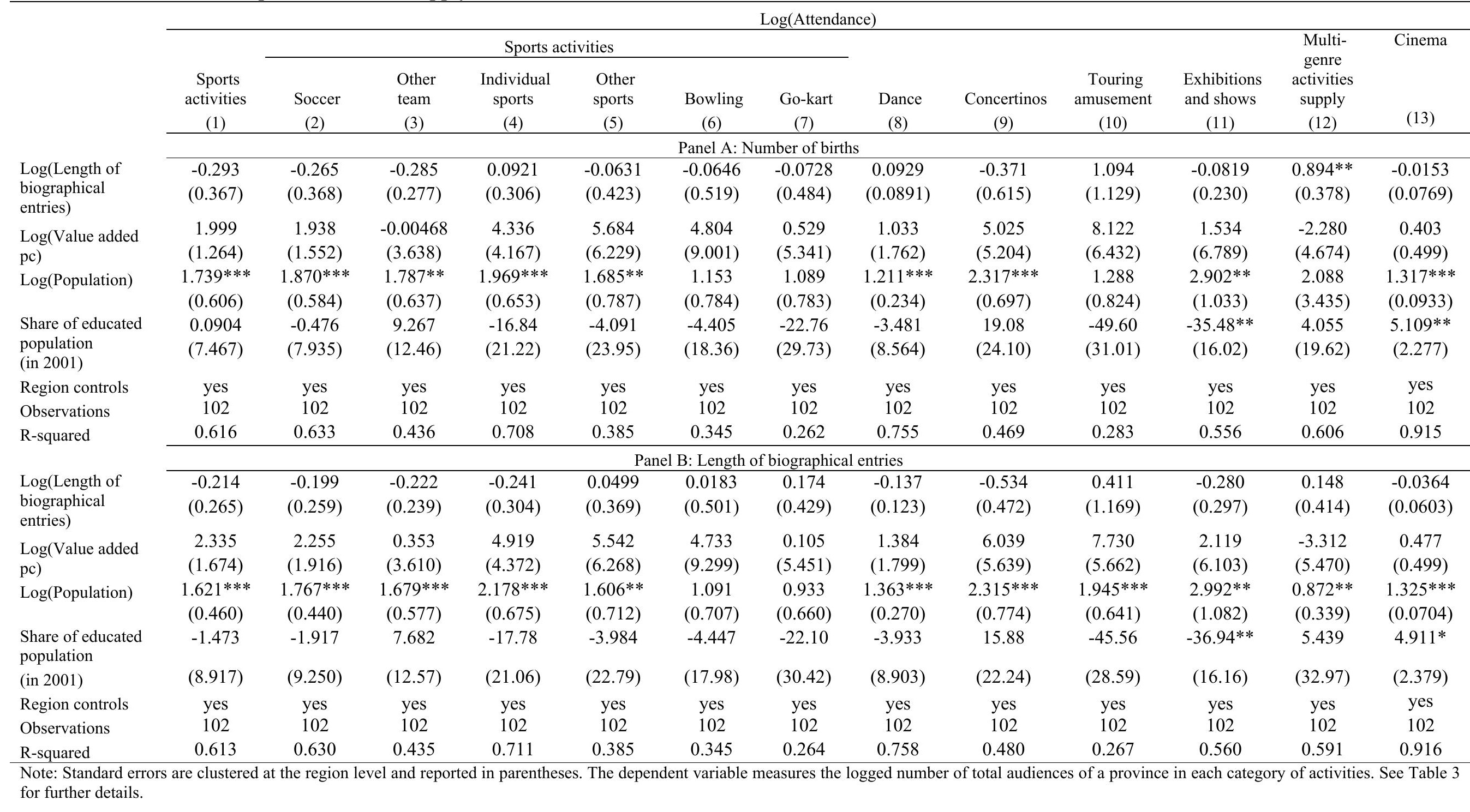


Table A4.4. Historical composer births and supply of other forms of entertainment: Total box office.

\begin{tabular}{|c|c|c|c|c|c|c|c|c|c|c|c|c|c|}
\hline & \multicolumn{13}{|c|}{$\log ($ Box office $)$} \\
\hline & \multicolumn{7}{|c|}{ Sports activities } & \multirow[b]{2}{*}{$\begin{array}{c}\text { Dance } \\
(8)\end{array}$} & \multirow[b]{2}{*}{$\begin{array}{c}\text { Concertinos } \\
(9) \\
\end{array}$} & \multirow[b]{2}{*}{$\begin{array}{c}\text { Touring } \\
\text { amusement } \\
(10) \\
\end{array}$} & \multirow[b]{2}{*}{$\begin{array}{c}\text { Exhibitions } \\
\text { and shows } \\
(11) \\
\end{array}$} & \multirow{2}{*}{$\begin{array}{l}\text { Multi- } \\
\text { genre } \\
\text { activities } \\
\text { supply } \\
(12)\end{array}$} & \multirow{2}{*}{$\begin{array}{c}\text { Cinema } \\
\text { (13) }\end{array}$} \\
\hline & $\begin{array}{c}\text { Sports } \\
\text { activities } \\
(1) \\
\end{array}$ & $\begin{array}{c}\text { Soccer } \\
(2) \\
\end{array}$ & $\begin{array}{l}\text { Other } \\
\text { team } \\
(3)\end{array}$ & $\begin{array}{l}\text { Individual } \\
\text { sports } \\
(4) \\
\end{array}$ & $\begin{array}{c}\text { Other } \\
\text { sports } \\
(5) \\
\end{array}$ & $\begin{array}{c}\text { Bowling } \\
(6)\end{array}$ & $\begin{array}{c}\text { Go-kart } \\
(7) \\
\end{array}$ & & & & & & \\
\hline \multicolumn{14}{|c|}{ Panel A: Number of births } \\
\hline $\begin{array}{l}\log (\text { Length of } \\
\text { biographical } \\
\text { entries) }\end{array}$ & $\begin{array}{l}-0.410 \\
(0.456)\end{array}$ & $\begin{array}{l}-0.344 \\
(0.475)\end{array}$ & $\begin{array}{l}-0.433 \\
(0.302)\end{array}$ & $\begin{array}{c}0.173 \\
(0.342)\end{array}$ & $\begin{array}{l}-0.370 \\
(0.719)\end{array}$ & $\begin{array}{l}-0.137 \\
(0.543)\end{array}$ & $\begin{array}{l}-0.0836 \\
(0.635)\end{array}$ & $\begin{array}{c}0.0730 \\
(0.0964)\end{array}$ & $\begin{array}{l}-0.404 \\
(0.776)\end{array}$ & $\begin{array}{c}1.244 \\
(1.310)\end{array}$ & $\begin{array}{c}0.00878 \\
(0.243)\end{array}$ & $\begin{array}{c}-1.046^{* * *} \\
(0.453)\end{array}$ & $\begin{array}{l}0.00103 \\
(0.0805)\end{array}$ \\
\hline $\begin{array}{l}\text { Log(Value added } \\
\text { pc) }\end{array}$ & $\begin{array}{l}2.666^{*} \\
(1.322)\end{array}$ & $\begin{array}{c}2.534 \\
(1.591)\end{array}$ & $\begin{array}{l}-0.840 \\
(4.492)\end{array}$ & $\begin{array}{c}6.438 \\
(4.566)\end{array}$ & $\begin{array}{c}6.404 \\
(8.237)\end{array}$ & $\begin{array}{c}3.483 \\
(10.29)\end{array}$ & $\begin{array}{c}3.219 \\
(7.394)\end{array}$ & $\begin{array}{c}1.153 \\
(1.617)\end{array}$ & $\begin{array}{c}4.010 \\
(6.209)\end{array}$ & $\begin{array}{c}10.10 \\
(7.732)\end{array}$ & $\begin{array}{c}3.162 \\
(7.574)\end{array}$ & $\begin{array}{l}-0.518 \\
(5.609)\end{array}$ & $\begin{array}{c}0.674 \\
(0.604)\end{array}$ \\
\hline Log(Population) & $\begin{array}{c}2.112 * * \\
(0.794)\end{array}$ & $\begin{array}{c}2.298 * * * \\
(0.788)\end{array}$ & $\begin{array}{c}2.232 * * * \\
(0.779)\end{array}$ & $\begin{array}{c}2.237 * * * \\
(0.704)\end{array}$ & $\begin{array}{c}2.057 * * \\
(0.946)\end{array}$ & $\begin{array}{l}1.602 * \\
(0.782)\end{array}$ & $\begin{array}{c}1.208 \\
(0.913)\end{array}$ & $\begin{array}{c}1.279 * * * \\
(0.249)\end{array}$ & $\begin{array}{c}2.802 * * * \\
(0.844)\end{array}$ & $\begin{array}{c}1.548 \\
(0.980)\end{array}$ & $\begin{array}{l}3.041 * * \\
(1.132)\end{array}$ & $\begin{array}{c}1.699 \\
(4.122)\end{array}$ & $\begin{array}{c}1.300 * * * \\
(0.105)\end{array}$ \\
\hline $\begin{array}{l}\text { Share of educated } \\
\text { population } \\
\text { (in 2001) }\end{array}$ & $\begin{array}{c}0.730 \\
(9.906)\end{array}$ & $\begin{array}{c}0.130 \\
(10.94)\end{array}$ & $\begin{array}{c}6.588 \\
(14.70)\end{array}$ & $\begin{array}{l}-20.55 \\
(27.25)\end{array}$ & $\begin{array}{l}-11.00 \\
(30.69)\end{array}$ & $\begin{array}{l}-11.03 \\
(18.80)\end{array}$ & $\begin{array}{l}-31.74 \\
(39.55)\end{array}$ & $\begin{array}{l}-3.935 \\
(9.180)\end{array}$ & $\begin{array}{c}28.34 \\
(31.52)\end{array}$ & $\begin{array}{l}-59.42 \\
(37.18)\end{array}$ & $\begin{array}{c}-39.58 * * \\
(17.20)\end{array}$ & $\begin{array}{c}0.885 \\
(23.55)\end{array}$ & $\begin{array}{l}4.752 * \\
(2.611)\end{array}$ \\
\hline Region controls & yes & yes & yes & yes & yes & yes & yes & yes & yes & yes & yes & yes & yes \\
\hline Observations & 102 & 102 & 102 & 102 & 102 & 102 & 102 & 102 & 102 & 102 & 102 & 102 & 102 \\
\hline \multicolumn{14}{|c|}{ Panel B: Length of biographical entries } \\
\hline $\begin{array}{l}\log (\text { Length of } \\
\text { biographical } \\
\text { entries) }\end{array}$ & $\begin{array}{l}-0.288 \\
(0.322)\end{array}$ & $\begin{array}{l}-0.235 \\
(0.313)\end{array}$ & $\begin{array}{l}-0.322 \\
(0.282)\end{array}$ & $\begin{array}{l}-0.339 \\
(0.371)\end{array}$ & $\begin{array}{l}-0.233 \\
(0.601)\end{array}$ & $\begin{array}{l}-0.0482 \\
(0.495)\end{array}$ & $\begin{array}{c}0.343 \\
(0.529)\end{array}$ & $\begin{array}{c}-0.177 \\
(0.135)\end{array}$ & $\begin{array}{l}-0.676 \\
(0.606)\end{array}$ & $\begin{array}{c}0.407 \\
(1.366)\end{array}$ & $\begin{array}{l}-0.225 \\
(0.324)\end{array}$ & $\begin{array}{c}0.191 \\
(0.469)\end{array}$ & $\begin{array}{l}-0.0281 \\
(0.0591)\end{array}$ \\
\hline $\begin{array}{l}\log (\text { Value added } \\
\text { pc) }\end{array}$ & $\begin{array}{l}3.113^{*} \\
(1.665)\end{array}$ & $\begin{array}{c}2.893 \\
(1.886)\end{array}$ & $\begin{array}{l}-0.330 \\
(4.410)\end{array}$ & $\begin{array}{c}7.277 \\
(4.739)\end{array}$ & $\begin{array}{c}6.746 \\
(8.561)\end{array}$ & $\begin{array}{c}3.525 \\
(10.64)\end{array}$ & $\begin{array}{c}2.415 \\
(7.644)\end{array}$ & $\begin{array}{c}1.583 \\
(1.647)\end{array}$ & $\begin{array}{c}5.324 \\
(6.815)\end{array}$ & $\begin{array}{c}9.791 \\
(6.773)\end{array}$ & $\begin{array}{c}3.667 \\
(6.878)\end{array}$ & $\begin{array}{l}-2.029 \\
(6.877)\end{array}$ & $\begin{array}{c}0.737 \\
(0.617)\end{array}$ \\
\hline Log(Population) & $\begin{array}{c}1.940 * * * \\
(0.613)\end{array}$ & $\begin{array}{c}2.150 * * * \\
(0.590)\end{array}$ & $\begin{array}{c}2.060 * * \\
(0.729)\end{array}$ & $\begin{array}{c}2.566^{* * *} \\
(0.740)\end{array}$ & $\begin{array}{l}1.888 * * \\
(0.855)\end{array}$ & $\begin{array}{l}1.518 * * \\
(0.648)\end{array}$ & $\begin{array}{c}0.949 \\
(0.663)\end{array}$ & $\begin{array}{c}1.437 * * * \\
(0.290)\end{array}$ & $\begin{array}{c}2.852 * * * \\
(0.935)\end{array}$ & $\begin{array}{c}2.329 * * * \\
(0.754)\end{array}$ & $\begin{array}{c}3.173 * * \\
(1.187)\end{array}$ & $\begin{array}{l}1.063 * * \\
(0.427)\end{array}$ & $\begin{array}{c}1.317 * * * \\
(0.0787)\end{array}$ \\
\hline $\begin{array}{l}\text { Share of educated } \\
\text { population } \\
\text { (in 2001) }\end{array}$ & $\begin{array}{l}-1.409 \\
(11.71)\end{array}$ & $\begin{array}{l}-1.630 \\
(12.84)\end{array}$ & $\begin{array}{c}4.248 \\
(14.74)\end{array}$ & $\begin{array}{l}-21.77 \\
(27.03)\end{array}$ & $\begin{array}{l}-12.80 \\
(29.92)\end{array}$ & $\begin{array}{l}-11.52 \\
(18.84)\end{array}$ & $\begin{array}{l}-30.32 \\
(40.46)\end{array}$ & $\begin{array}{l}-4.612 \\
(9.555)\end{array}$ & $\begin{array}{c}24.42 \\
(29.22)\end{array}$ & $\begin{array}{l}-55.10 \\
(34.33)\end{array}$ & $\begin{array}{c}-40.60 * * \\
(17.16)\end{array}$ & $\begin{array}{c}2.340 \\
(39.44)\end{array}$ & $\begin{array}{c}4.624 \\
(2.730)\end{array}$ \\
\hline Region controls & $\begin{array}{l}\text { yes } \\
102\end{array}$ & $\begin{array}{l}\text { yes } \\
102\end{array}$ & $\begin{array}{l}\text { yes } \\
102\end{array}$ & $\begin{array}{l}\text { yes } \\
102\end{array}$ & $\begin{array}{l}\text { yes } \\
102\end{array}$ & $\begin{array}{l}\text { yes } \\
102\end{array}$ & $\begin{array}{l}\text { yes } \\
102\end{array}$ & $\begin{array}{l}\text { yes } \\
102\end{array}$ & $\begin{array}{l}\text { yes } \\
102\end{array}$ & $\begin{array}{l}\text { yes } \\
102\end{array}$ & $\begin{array}{l}\text { yes } \\
102\end{array}$ & $\begin{array}{l}\text { yes } \\
102\end{array}$ & $\begin{array}{l}\text { yes } \\
102\end{array}$ \\
\hline R-squared & 0.582 & 0.621 & 0.418 & 0.708 & 0.347 & 0.347 & 0.244 & 0.728 & 0.466 & 0.269 & 0.598 & 0.578 & 0.914 \\
\hline
\end{tabular}




\section{Appendix 5. Robustness Tests.}

This Appendix describes some of the robustness tests that have been conducted in order to test the reliability of the disclosed results. ${ }^{23}$

The disclosed association with contemporary entertainment activity supply is conducted for the last available year 2007. The database is however also provided for the preceding year 2006, which I include next in a robustness specification in order to investigate the consistency of the results. The estimations are summarized in columns 1 and 2 in Table A5.1. It can be viewed that the correlation coefficients are very similar in sign, size and significance with the baseline specification for the year $2007 .^{24}$

Table A5.1. Robustness tests.

\begin{tabular}{|c|c|c|c|c|}
\hline & \multicolumn{4}{|c|}{ Log(Performances) } \\
\hline & $\begin{array}{c}\text { Classical } \\
\text { concerts, } \\
2006 \\
(1)\end{array}$ & $\begin{array}{c}\text { Opera, } \\
2006 \\
(2) \\
\end{array}$ & $\begin{array}{c}\text { Classical } \\
\text { concert } \\
(3) \\
\end{array}$ & $\begin{array}{c}\text { Opera } \\
(4)\end{array}$ \\
\hline & \multicolumn{4}{|c|}{ Panel A: Number of births } \\
\hline Log(Composer births) & $\begin{array}{l}0.247 * \\
(0.121)\end{array}$ & $\begin{array}{l}0.0850 \\
(0.111)\end{array}$ & $\begin{array}{l}0.256^{* * *} \\
(0.0882)\end{array}$ & $\begin{array}{l}0.240 * \\
(0.120)\end{array}$ \\
\hline Log(Tourist arrivals) & & & $\begin{array}{l}0.0959 * * \\
(0.0364)\end{array}$ & $\begin{array}{l}0.00353 \\
(0.0372)\end{array}$ \\
\hline Value added pc controls & yes & yes & yes & yes \\
\hline Population controls & yes & yes & yes & yes \\
\hline Share of educated population & yes & yes & yes & yes \\
\hline Region controls & yes & yes & yes & yes \\
\hline Observations & 102 & 102 & 102 & 102 \\
\hline \multirow[t]{2}{*}{ R-squared } & 0.428 & 0.686 & 0.357 & 0.651 \\
\hline & \multicolumn{4}{|c|}{ Panel B: Length of biographical entries } \\
\hline $\begin{array}{l}\text { Log(Length of biographical } \\
\text { entries) }\end{array}$ & $\begin{array}{l}0.177 * * \\
(0.0743)\end{array}$ & $\begin{array}{l}0.175 * * \\
(0.0677)\end{array}$ & $\begin{array}{c}0.267 * * * \\
(0.0809)\end{array}$ & $\begin{array}{l}0.256 * * \\
(0.0944)\end{array}$ \\
\hline Log(Tourist arrivals) & & & $\begin{array}{c}0.0910 * * * \\
(0.0294)\end{array}$ & $\begin{array}{l}-0.00877 \\
(0.0361)\end{array}$ \\
\hline Value added pc controls & yes & yes & yes & yes \\
\hline Population controls & yes & yes & yes & yes \\
\hline Share of educated population & yes & yes & yes & yes \\
\hline Region controls & yes & yes & yes & yes \\
\hline Observations & 102 & 102 & 102 & 102 \\
\hline R-squared & 0.415 & 0.628 & 0.378 & 0.590 \\
\hline
\end{tabular}

Note: Standard errors are clustered at region level and reported in parentheses. The dependent variable measures the logged number of performances per capita of a province in each activity. This estimation considers only a sub-sample of composers who have been born and died in the same province. 'Composer births' measures the total number of composer births (for the restricted sample) in a province that occurred during Renaissance (i.e. between 1400 and 1600). 'Length of biographical entries' measures the total number

\footnotetext{
${ }^{23}$ For simplicity I report only results for classical concerts and opera performances.

${ }^{24}$ It is unfortunately out of scope to investigate the presence of any differences between longer periods of time as adequate cultural supply data is not available. In the Persistency subsection I follow however a different approach in order to study inter-temporal patterns.
} 
of words written on composers (from the restricted sample) born in a province during Renaissance. The database is recorded on the province level and the 2007 borders are utilised. $* * * / * * / *$ indicate estimates that are significantly different from zero at $99 / 95 / 90 \%$ confidence.

In a recent study Borowiecki and Castiglione (2014) have argued that tourism flows coincide strongly with cultural participation. If this was the case, our results could be biased by unobserved geographic variation in tourism flows. In order to address this potential concern I measure tourism flows by accounting for the number of visitors to a province, Italians or foreigners, who stayed at least one night in a tourist accommodation in the year 2007. The data set is obtained from the Italian National Institute of Statistics and is based on a wide definition of tourism accommodation. ${ }^{25}$ The results are summarized in columns 3 and 4. The coefficients of main interest remain very stable and imply that our findings are not driven by tourism flows.

The issue of migration has been neglected so far. One could worry that the birth locations and work locations, in which the effective creativity stimulating forces would be located, have not been necessary the same. It is fairly out of scope to measure the time spent by each composer in any of the provinces for a sample of this size. Furthermore, for many of the covered individuals information of this detail is not available. However, one could study the work location history for a sub-sample. I select therefore a sub-sample of prominent composers based on Murray (2003) who provides a list of the 523 most important composers of all times. This list includes 42 composers who were born in Italy during the $15^{\text {th }}$ or $16^{\text {th }}$ centuries. Using Grove Music Online (2011) one can then track the migration histories for this group. The results imply that the average of those 42 composers has spent around 38.7 years in the province where he was born. Considering the average longevity of 59.1 (standard deviation 9.3), this implies a share of around 65\%. Subtracting a person's infancy and time devoted to education, 21.3 working years (standard deviation 17.2) have been spent in the province of birth. This is about half of a composer's duration of career (41.7 years, standard deviation 10.1). These are very significant periods of life spent in the province of birth. Furthermore, it is very interesting to observe the similarity of those estimates with the share of composers from the full-sample who were born and died in the same province.

In addition to the above disclosed patterns, it could be further argued that the association between a birth location and a typical work location for music exists, even if it might be lagged. A place that becomes a meaningful destination for a certain group of artists attracts immigration, contributing so to the development of a local creative cluster. The more

\footnotetext{
25 Tourism accommodation includes all types of facilities: hotels, motels, residences, camp sites, holiday villages, farm accommodation, holiday flat and houses, hostels, alpine refuges and so on.
} 
established an artistic discipline becomes in a location, the stronger are the forces stimulating the consecutive attraction from other regions or local emergence of outstanding talent. In addition, more established locations experience improvements of cultural infrastructure, education practices and institutional arrangements, contributing so further to the birth frequency of meaningful artists. Coherent migration patterns are established by O'Hagan and Borowiecki (2010), who analyse birth locations, migration flows and tendencies to cluster in certain cities for classical composers born between 1750 and 1899. This is a period during which Paris has been globally the predominant location for music, especially in the earlier decades of the analysed period. In the 1750 to 1800 period, Paris has been the main work location for $40 \%$ of composers covered by the authors' sample, followed in the first half of the $19^{\text {th }}$ century by a concentration of $36 \%$ and $22 \%$ in the second half. These are very high proportions which clearly decline over time. The proportion of births of composers that occurred in Paris during the same period is comparably high however it is exhibiting an upward trend. Out of the composers working in Paris during each of the three half century periods, respectively, 27\%, 38\% and $47 \%$ have been born in the French capital. These patterns point at the existence of a lagged relationship between composer concentration rate due to immigration and the consecutive increase in the frequency of births. ${ }^{26}$

An interesting question deals with the role of historical persistency of population density and agglomeration economies in cultural production. Cultural production benefits not only due to geographic concentration of artistic talent (Borowiecki, 2013), but also urban density may be a significant determinant of agglomerations by facilitating consumption (Brueckner et al., 1999; Glaeser et al., 2001). It is thus desired to disentangle the current findings of the paper into effects stemming from the overall persistency of preferences for culture and agglomeration economies. In support of the role of the former one are the sets of estimations with non-cultural activities as the dependent variable: there is no association found between historical composer births and contemporary entertainment activity. If the results were attributable to agglomeration effects, it is not clear why would only cultural production benefit from them and not, for example, sports activities, where the idea of peer effects is equally strong established.

\footnotetext{
${ }^{26}$ Similar patterns emerge for the previously introduced sub-sample of 42 prominent composers, who during the $16^{\text {th }}$ century have primary migrated towards the Northern provinces, that is to the areas which have been most important for music in the preceding century.
} 
Table A5.2. Historical composer births and persistency of population density.

\begin{tabular}{|c|c|c|c|c|}
\hline & \multicolumn{4}{|c|}{ Log(Performances) } \\
\hline & $\begin{array}{c}\text { Classical } \\
\text { concerts } \\
(1)\end{array}$ & $\begin{array}{c}\text { Opera } \\
(2)\end{array}$ & $\begin{array}{c}\text { Classical } \\
\text { concerts } \\
(3)\end{array}$ & $\begin{array}{c}\text { Opera } \\
(4)\end{array}$ \\
\hline & \multicolumn{4}{|c|}{ Panel A: Number of births } \\
\hline Log(Composer births) & $\begin{array}{l}0.218^{*} \\
(0.112)\end{array}$ & $\begin{array}{c}0.194 \\
(0.130)\end{array}$ & & \\
\hline $\begin{array}{l}\log (\text { Length of biographical } \\
\text { entries })\end{array}$ & & & $\begin{array}{l}0.258^{* *} \\
(0.0929)\end{array}$ & $\begin{array}{c}0.0824 \\
(0.0913)\end{array}$ \\
\hline Log(Historical population) & $\begin{array}{c}0.118 \\
(0.0776)\end{array}$ & $\begin{array}{c}0.154 \\
(0.108)\end{array}$ & $\begin{array}{c}0.128^{*} \\
(0.0646)\end{array}$ & $\begin{array}{c}0.180^{*} \\
(0.0987)\end{array}$ \\
\hline Value added pc controls & yes & yes & yes & yes \\
\hline Population controls & yes & yes & yes & yes \\
\hline Share of educated population & yes & yes & yes & yes \\
\hline Region controls & yes & yes & yes & yes \\
\hline Observations & 102 & 102 & 102 & 102 \\
\hline R-squared & 0.351 & 0.666 & 0.379 & 0.658 \\
\hline
\end{tabular}

Note: 'Historical population' measures population in 1600 in a province by utilising 2007 borders. See Table A5.1.

Data on historical population at the province level are not available. It is thus unfortunately not feasible to record composer births in relation to total births in each province and so far the paper has primary relied on using contemporary population statistics. An alternative approach is to use Bairoch's city population data. ${ }^{27}$ Table A5.2 reports the additional robustness test where historical city population within a province is included in order to capture any historical agglomeration effects. Columns 1 to 4 report the results for a specification that includes city population in a province in 1600 . The results are consistent with the baseline specification and would remain stable if population from any of the different years provided by Bairoch was used. ${ }^{28}$ The point estimates on the historical urban population are insignificant, suggesting that the main results are unlikely attributable to the persistency of agglomeration effects.

Another possible unobservable factor driving our results could be historical human capital. Campante and Glaeser (2009) show that human capital is important to explain the divergent path of cities and high human capital is concentrated in the high amenity locations (Falck et al., 2011). Testing the role of historical human capital is limited in this research as no records are available for education levels in Italy in the past. Assuming persistency in

\footnotetext{
${ }^{27}$ The shortcoming of this is of course that we do not know how important was the city within a province. Obviously two provinces with one city of the same size each, but one with a small province total population (i.e. high urbanization rate) while the other with a large province total population (i.e. low urbanization rate), have different agglomeration effects on cultural production.

${ }^{28}$ One might worry that the estimation results from this specification are biased due to multicollinearity, as historical population distribution is likely to be correlated with contemporary population distribution. A model that excludes contemporary population size delivers nonetheless consistent results (not reported).
} 
human capital, historical education could be possibly approximated with contemporary education levels: A high level of human capital may have historically stimulated the emergence of composers and shapes also contemporary cultural supply. This is in line with Campante and Glaeser (2009) and constitutes an additional motivation for the inclusion of the control variable for contemporary education levels.

An alternative way of approximating historical education levels could be by the means of an indicator function that denotes the existence of a university in the vicinity during the Renaissance. Fourteen out of the 107 contemporary provinces have a university which was founded before 1500 (Hyde, 1991). The correlation between the historical presence of a university and contemporary educational attainment measured with the population size that have at least a secondary school degree in 2001 is at 0.37 very high and statistically significant.

The estimation is reported in Table A5.3. It can be observed that the association between composer births or quality remains significant and consistent in size for both activities. The baseline associations do not get distorted through the inclusion of education controls, which suggests that some other determinants, related to the incidence of composer birth or quality, are relevant. Possibly those determinants could be attributable to the persistency of preference traits of a society. Alternatively, the disclosed patterns might be influenced by the endurance of some industrial settings, such as more advanced music production technology, superior infrastructure or better professional networks. The results provide some indication that certain productivity enhancing factors have prevailed over long periods of time, resulting in a remarkable geographic persistency of cultural activity.

Table A5.3. Persistency of cultural preferences and historical human capital.

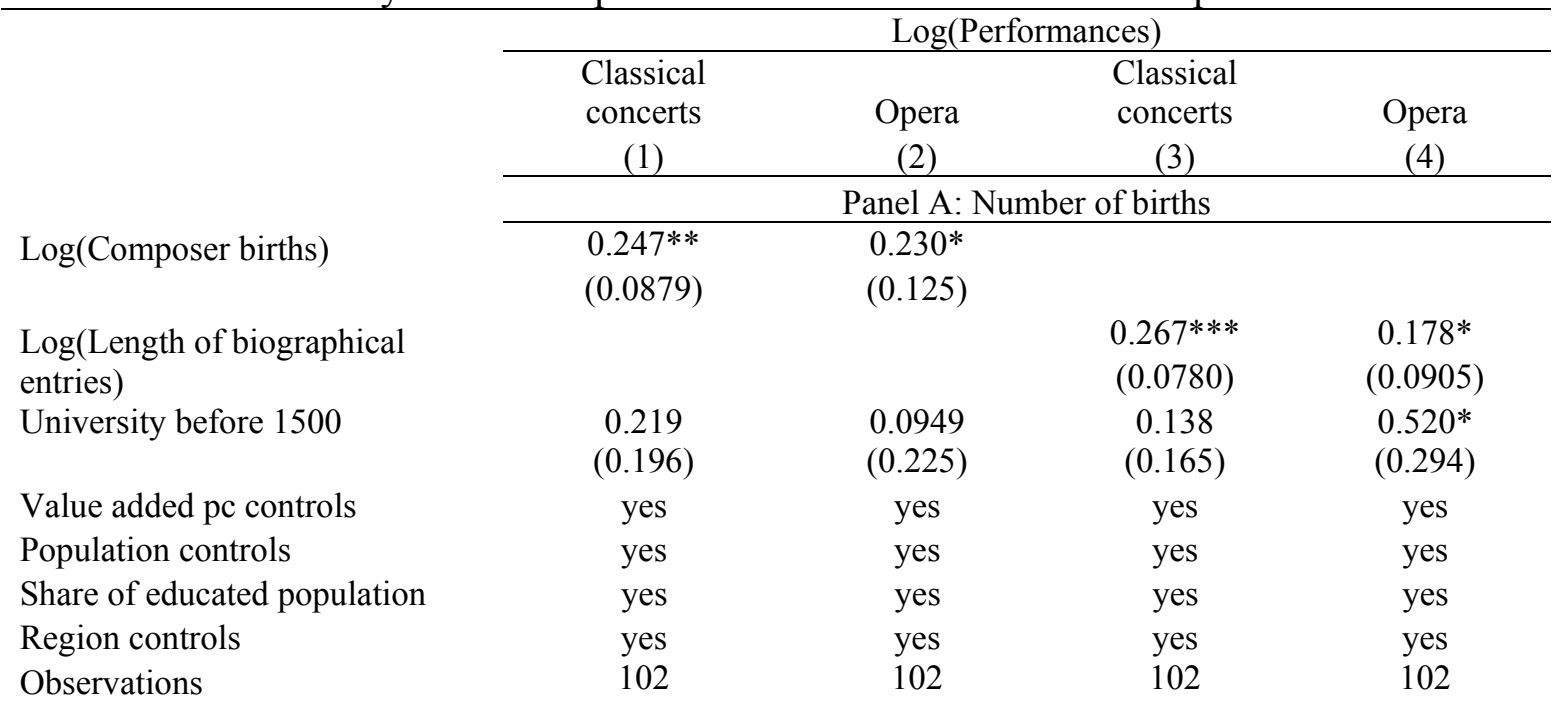


Note: 'University before 1500 ' indicates with a dummy variable the provinces that have a university founded before 1500 (Hyde, 1991). See Table A5.1. 


\section{Appendix 6. Explanatory Power.}

Based on a wide range of robustness tests conducted and discussed above it has been disclosed that the association between historical composers and contemporary cultural supply is very stable. An arising question deals with the explanatory power of the relationship: how much of contemporary cultural supply variation is associated with historical composer births. The analysis is presented in Table A6 and the focus is directed at the coefficient of determination. Historical cultural activity explains $6.8-7.6 \%$ of the variation of classical concerts, depending on which measure is used, and around $9.1-20.7 \%$ of opera performances.

Table A6. Explanatory power of composer births in Renaissance.

\begin{tabular}{|c|c|c|c|c|}
\hline & \multicolumn{4}{|c|}{ Log(Performances) } \\
\hline & $\begin{array}{c}\text { Classical } \\
\text { concerts } \\
(1)\end{array}$ & $\begin{array}{c}\text { Opera } \\
(2) \\
\end{array}$ & $\begin{array}{l}\text { Classical } \\
\text { concerts } \\
\text { (3) }\end{array}$ & $\begin{array}{l}\text { Opera } \\
(4) \\
\end{array}$ \\
\hline Log(Composer births) & $\begin{array}{l}0.293 * * \\
(0.103)\end{array}$ & $\begin{array}{c}0.648^{* * * *} \\
(0.110)\end{array}$ & & \\
\hline $\begin{array}{l}\log (\text { Length of } \\
\text { biographical entries })\end{array}$ & & & $\begin{array}{l}0.310^{* * *} \\
(0.0789)\end{array}$ & $\begin{array}{c}0.429^{* * *} \\
(0.0932)\end{array}$ \\
\hline Observations & 107 & 107 & 107 & 107 \\
\hline R-squared & 0.068 & 0.207 & 0.076 & 0.091 \\
\hline
\end{tabular}




\section{References for Online Appendix}

Bairoch, P., J. Batou and P. Chevre. 1988. Population of European Cities from 800-1860. Geneva: Geneva University, Centre of International Economic History.

Borowiecki, K.J. 2013. 'Geographic Clustering and Productivity: An Instrumental Variable Approach for Classical Composers.' Journal of Urban Economics, 73, 94-110.

Borowiecki, K.J. and C. Castiglione. 2014. 'Cultural Participation and Tourism Flows.' Tourism Economics, 20(2).

Brueckner, J.K., J.F. Thisse and Y. Zenou. 1999. 'Why is central Paris rich and downtown Detroit poor? An amenity-based theory.' European Economic Review, 43, 91-107.

Campante, F. and E.L. Glaeser. 2009. 'Yet another Tale of Two Cities: Buenos Aires and Chicago.' NBER Working Paper No. 15104.

Falck, O., M. Fritsch and S. Heblich. 2011. 'The Phantom of the Opera: Cultural Amenities, Human Capital, and Regional Economic Growth.' Labor Economics, 18(6), 755-766.

Glaeser E.L., J. Kolko and A. Saiz, 2001. 'Consumer city.' Journal of Economic Geography, $1(1), 27-50$.

Hyde, J.K. 1991. 'Universities and Cities in Medieval Italy', in Bender, T. (Ed.), The University and the City: From Medieval Origins to the Present. Oxford: Oxford University Press.

Murray, C. 2003. Human Accomplishment - The Pursuit of Excellence in the Arts and Sciences, 800 B.C. to 1950. New York: Harper Collins.

O'Hagan, J. and K.J. Borowiecki. 2010. 'Birth Location, Migration and Clustering of Important Composers: Historical Patterns.' Historical Methods, 43(2), 81-90. 